ARTICLE

DOI: $10.1038 / s 41467-017-00417-7$

\title{
Redox reactions and weak buffering capacity lead to acidification in the Chesapeake Bay
}

\author{
Wei-Jun Cai (1) 1, Wei-Jen Huang',2, George W. Lutherlll (1) ${ }^{1}$, Denis Pierrot ${ }^{3}$, Ming Li ${ }^{4}$, Jeremy Testa ${ }^{5}$, \\ Ming Xue ${ }^{1,6}$, Andrew Joesoef ${ }^{1}$, Roger Mann7, Jean Brodeur ${ }^{1}$, Yuan-Yuan Xu1 , Baoshan Chen (1) 1, Najid Hussain ${ }^{1}$, \\ George G. Waldbusser (iD ${ }^{8}$, Jeffrey Cornwell ${ }^{4} \&$ W. Michael Kemp ${ }^{4}$
}

The combined effects of anthropogenic and biological $\mathrm{CO}_{2}$ inputs may lead to more rapid acidification in coastal waters compared to the open ocean. It is less clear, however, how redox reactions would contribute to acidification. Here we report estuarine acidification dynamics based on oxygen, hydrogen sulfide $\left(\mathrm{H}_{2} \mathrm{~S}\right), \mathrm{pH}$, dissolved inorganic carbon and total alkalinity data from the Chesapeake Bay, where anthropogenic nutrient inputs have led to eutrophication, hypoxia and anoxia, and low $\mathrm{pH}$. We show that a $\mathrm{pH}$ minimum occurs in middepths where acids are generated as a result of $\mathrm{H}_{2} \mathrm{~S}$ oxidation in waters mixed upward from the anoxic depths. Our analyses also suggest a large synergistic effect from river-ocean mixing, global and local atmospheric $\mathrm{CO}_{2}$ uptake, and $\mathrm{CO}_{2}$ and acid production from respiration and other redox reactions. Together they lead to a poor acid buffering capacity, severe acidification and increased carbonate mineral dissolution in the USA's largest estuary.

\footnotetext{
${ }^{1}$ School of Marine Science and Policy, University of Delaware, Newark, DE 19716, USA. ${ }^{2}$ Department of Oceanography, National Sun Yat-sen University, Kaohsiung 80424, Taiwan. ${ }^{3}$ RSMAS, University of Miami, Miami, FL 33149, USA. ${ }^{4}$ Horn Point Laboratory, University of Maryland Center for Environmental Science, Cambridge, MD 21613, USA. ${ }^{5}$ Chesapeake Biological Laboratory, University of Maryland Center for Environmental Science, Solomons, MD 20688, USA. ${ }^{6}$ State Key Laboratory of Petroleum Pollution Control, CNPC Research Institute of Safety and Environmental Technology, Beijing 102206, China.

${ }^{7}$ Virginia Institute of Marine Science, Gloucester Point, VA 23062, USA. ${ }^{8}$ College of Earth, Ocean, and Atmospheric Sciences, Oregon State University, 104 COAS Admin. BIdg., Corvallis, OR 97331, USA. Correspondence and requests for materials should be addressed to W.-J.C. (email: wcai@udel.edu)
} 
A nthropogenic carbon dioxide $\left(\mathrm{CO}_{2}\right)$ has increased more rapidly in the atmosphere since the Industrial Revolution than natural $\mathrm{CO}_{2}$ increase in any period of the last $\sim 800,000$ years $^{1,2}$; consequently, it has been known that the uptake of $\mathrm{CO}_{2}$ by the ocean has altered surface seawater acidbased chemistry lowering $\mathrm{pH}$ by about 0.1 unit and calcium carbonate saturation state by roughly 0.5 . This process, known popularly as ocean acidification (OA) for over a decade, will continue to decrease seawater $\mathrm{pH}$ by about 0.3 units by the end of the century ${ }^{3,4}$. It is likely that OA will cause detrimental effects on the health of marine organisms and ecosystems and alter the associated biogeochemical processes ${ }^{5-7}$.

Recent research indicates that eutrophication can exacerbate OA, where respiratory processes contribute a far greater acidification in the coastal oceans relative to the open ocean ${ }^{8-13}$. Coastal eutrophication occurs with increased inputs of nutrients from the application of chemical fertilizers, discharges of human and animal wastes, and atmospheric $\mathrm{NO}_{\mathrm{x}}$ inputs from fossil fuel burning, which have fueled large algal blooms in many coastal water bodies, especially those near population centers ${ }^{14}$. It is well known that decomposition of algal organic matter from highly productive surface water leads to the development of seasonally low oxygen (hypoxic) or even zero oxygen (anoxic) bottom waters in many coastal water bodies in the world ${ }^{15}, 16$. However the coupling between redox and acid-base chemistry has not been explored extensively in seasonally anoxic and partially mixed estuaries nor in permanently anoxic deep basins although redox chemistry and $\mathrm{pH}$ have been reported before in the latter ${ }^{13,17-22}$. Specifically, it is not known how subsurface water $\mathrm{pH}$ dynamics are influenced by anaerobic respiration and the oxidation of reduced chemical species (notably $\mathrm{H}_{2} \mathrm{~S}$ ) in seasonally low oxygen $\left(\mathrm{O}_{2}\right)$ estuaries around the world let alone the interaction of these processes with the anthropogenic $\mathrm{CO}_{2}$ induced $\mathrm{OA}$.

The Chesapeake Bay is the largest estuary in the United States with a well-documented history of eutrophication over the past half century ${ }^{23-25}$. A recent report demonstrates that some regions of the bay have suffered a long-term $\mathrm{pH}$ decline related to eutrophication ${ }^{26}$. However, few process studies have examined the $\mathrm{CO}_{2}$ system and $\mathrm{pH}$ in the Chesapeake, and those that exist have focused on tributaries in the southern reaches of the estu$\operatorname{ary}^{27,28}$. To address the coupling between acid-base chemistry and redox chemistry and its contribution to coastal OA, we sampled the water column repeatedly for several days within a deep basin of the main-stem bay in August 2013 and 2014, a time of peak hypoxia and anoxia, and these data were supplemented with an April 2015 (pre-hypoxia) study. In this paper, we report and explain the occurrence of a $\mathrm{pH}$ minimum at and above the oxic-anoxic boundary due to $\mathrm{H}_{2} \mathrm{~S}$ oxidation. We further demonstrate how a combination of processes drives down $\mathrm{pH}$ and aragonite mineral saturation state, leading to $\mathrm{CaCO}_{3}$ mineral dissolution in subsurface waters. Finally, we present a general geochemical model to explain why large eutrophic estuaries, exemplified by the Chesapeake Bay, are particularly vulnerable to the acidification stresses caused by the increase of anthropogenic atmospheric $\mathrm{CO}_{2}$ and aquatic eutrophication and respiration.

\section{Results}

Acidification due to eutrophication-induced local $\mathrm{CO}_{2}$ uptake. Partial pressure of carbon dioxide $\left(p \mathrm{CO}_{2}\right)$ in surface waters of the Chesapeake Bay exceeded $1600 \mu \mathrm{atm}$ in its upper reach and was below the atmospheric level $(\sim 390 \mu \mathrm{atm})$ in the mid-bay for all three cruises between spring and summer (Fig. 1a, b, Table 1, Supplementary Fig. 1, and Methods). The low $p \mathrm{CO}_{2}$ was accompanied by high chlorophyll-a, a phytoplankton biomass proxy, and supersaturated dissolved $\mathrm{O}_{2}$ for much of the year in the mid- and lower-bay (Supplementary Figs. 2-5), indicating net biological production fueled by high riverine nutrient loading. The low surface $p \mathrm{CO}_{2}$ should lead to atmospheric $\mathrm{CO}_{2}$ invasion

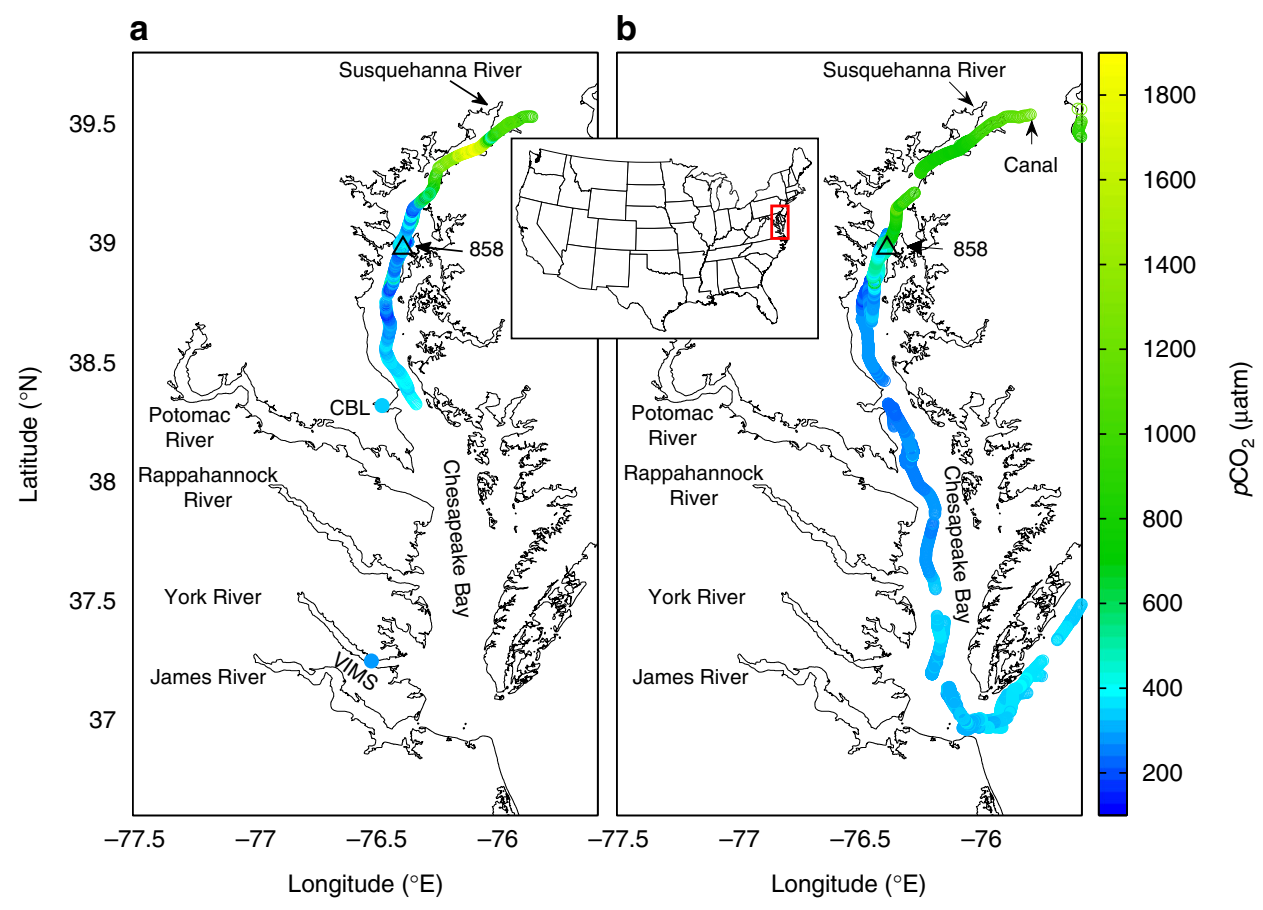

Fig. 1 Measured surface water $p \mathrm{CO}_{2}$ overlapped on a site map of the Chesapeake Bay. a 8-15 August 2013 and b 11-16 April 2015. Data were collected underway aboard R/V Sharp and supplemented with dockside measurements at the Chesapeake Biological Laboratory (CBL) and Virginia Institute of Marine Science (VIMS) during the August cruise. The inserted map shows the general location of the bay. Station 858 is our focused study site. The cruise average of atmospheric and surface water $p \mathrm{CO}_{2}$ values and monthly wind speed are given in Table 1 . The $p \mathrm{CO}_{2}$ range was $340-590 \mu$ atm near $\mathrm{CBL}$ and 290-550 $\mu \mathrm{atm}$ near VIMS, with the lower ends represent incoming bay water during high tides and the high ends representing outgoing sub-estuarine waters during low tides 
and may contribute to water column $\mathrm{CO}_{2}$ accumulation and acidification, particularly given atmospheric concentrations are $\sim 40 \%$ greater than the pre-industrial and bay has a long water residence time of 100 days $^{24}$. While complete water column mixing and destratification occurs occasionally during storms ${ }^{29,30}$, smaller wind events more frequently mix water and chemical species down to middle depths (Fig. 2a, Supplementary Figs. 6 and 7). Turbulence in the tidally driven bottom boundary layer will then mix the chemical species in the bottom water ${ }^{31}$. We have estimated the air-to-water $\mathrm{CO}_{2}$ flux and its impact on water column total dissolved inorganic carbon (DIC) and $\mathrm{pH}$ over the period of spring to summer (Table 1). To calculate the effect of DIC increase on bottom water $\mathrm{pH}$ decrease, we have modified the popularly used CO2SYS program to include
$\mathrm{H}_{2} \mathrm{~S}-\mathrm{HS}^{-}$and $\mathrm{NH}_{3}-\mathrm{NH}_{4}{ }^{+}$species in the acid-base equilibrium calculations as the bottom water in August contains these reduced chemical species (Methods). The resulting bottom-water $\mathrm{pH}$ decreases $(0.08-0.13$ over the spring-summer period; Table 1$)$ are significant when compared with $\mathrm{pH}$ decrease due to $\mathrm{CO}_{2}$ uptake from the atmosphere in the open ocean (0.11). However the time scales of acidification due to local $\mathrm{CO}_{2}$ uptake (months) are much shorter than open ocean uptake (decadal to centennial).

We also note that acidification induced by local $\mathrm{CO}_{2}$ uptake is caused by both increased atmospheric $\mathrm{CO}_{2}$ and coastal eutrophication. This is in sharp contrast with the $\mathrm{CO}_{2}$ uptake in the open ocean where atmospheric forcing is comparable to the coastal ocean but biological $\mathrm{CO}_{2}$ removal and physical mixing are less intense or frequent. Clearly, climate change, anthropogenic

Table 1 Air-sea $\mathrm{CO}_{2}$ flux and its impact on bottom-water DIC and pH in the middle Chesapeake Bay

\begin{tabular}{|c|c|c|c|c|c|c|}
\hline Month Year & $\begin{array}{l}\text { Air } \mathrm{pCO}_{2} \\
\mu \text { atm }\end{array}$ & $\begin{array}{l}\text { Water } \mathrm{pCO}_{2} \\
\mu \text { atm }\end{array}$ & $\begin{array}{l}\text { Wind speed } \\
\mathrm{m} \mathrm{s}^{-1}\end{array}$ & 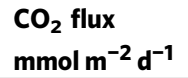 & $\begin{array}{l}\Delta \text { DIC } \\
\mu \mathrm{mol} \mathrm{kg}{ }^{-1}\end{array}$ & $\Delta \mathrm{pH}$ \\
\hline August 2013 & $380.2 \pm 11.2$ & $309.1 \pm 99.3$ & $4.4 \pm 2.3$ & $-4.3 \pm 0.4$ & 21.2 & -0.081 \\
\hline August 2014 & $373.1 \pm 9.1$ & $251.6 \pm 70.9$ & $4.2 \pm 2.2$ & $-6.7 \pm 0.7$ & 33.1 & -0.13 \\
\hline
\end{tabular}

The mid-bay region is defined as the area between 37.9 and $39.0^{\circ}$ N. Monthly averaged wind data were calculated from National Data Buoy Center station\# COVM2-8577018 at Cove Point LNG Pier, MD
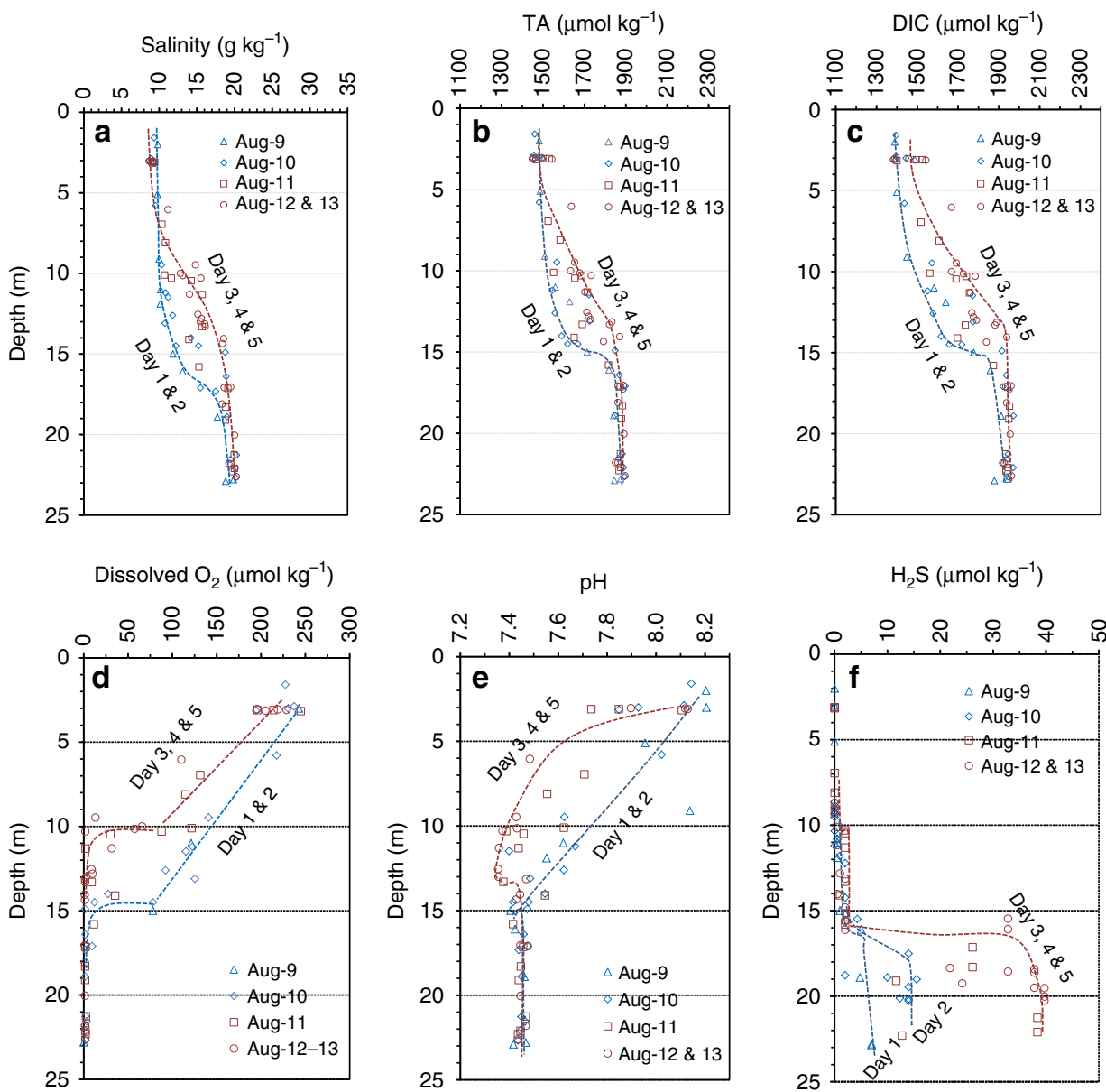

Fig. 2 Vertical distributions of measured chemical properties at the focused study site in August 2013. a Salinity, b total alkalinity (TA), c dissolved inorganic carbon (DIC), d dissolved oxygen, e pH $\left(25^{\circ} \mathrm{C}\right.$ and NBS scale), and $\mathbf{f} \mathrm{H}_{2} \mathrm{~S}$ concentration. See Fig. 1 for location (station 858 ). The lines are the lower and upper boundaries between days 1 and 2 and days 3-5, respectively. August 2014 data are presented in Supplementary Fig. 8 for comparison and affirmation of the 2013 observations 
inputs, and natural processes have jointly altered the carbon cycle and stressed aquatic environments in the coastal zone.

The spatial gradients of $p \mathrm{CO}_{2}$ observed here and inferred net autotrophy are consistent with prior investigations using oxygenbased approaches to measuring primary production and respiration. Kemp et al. ${ }^{25}$ concluded that the Chesapeake Bay was net autotrophic overall, but heterotrophic conditions (where respiration exceeded photosynthesis) prevailed in low-salinity regions where we measured supersaturated $p \mathrm{CO}_{2}$ (Fig. 1a, b, Supplementary Fig. 1) and $\mathrm{O}_{2}$ was consistently under saturated (Supplementary Figs. 2b, 3-5). Dissolved $\mathrm{O}_{2}$ tends to be undersaturated in northern regions of the bay given high respiration rates associated with external loads of organic carbon ${ }^{32}$.

These heterotrophic conditions gave way to a near balanced and an autotrophic metabolism in the mid- and lower-bay, leading to a mean, bay-wide net ecosystem production, which is consistent with strong under saturation of $p \mathrm{CO}_{2}$ in these seaward regions (Fig. 1a, b and Supplementary Fig. 1). The mid- and lower-bay stations (CB3.3C and south) tended towards $\mathrm{O}_{2}$ supersaturation during most months of the year, especially during the warmer months (Supplementary Figs. 2b, 4 and 5). Despite some interannual variability in the seasonal pattern of dissolved $\mathrm{O}_{2}$ saturation, the years of 2013-2015 indicate similar seasonal patterns. Oxygen-based estimates of metabolism showed consistent surface-layer net $\mathrm{O}_{2}$ production and bottom-layer net $\mathrm{O}_{2}$ consumption, the rates of which were highly correlated ${ }^{32}$. Although oxygen-based methods could not be applied under oxygen-depleted conditions, independent measures of sulfate reduction (SR) in sediments, which dominated the benthic metabolism during warm months and led to significant sediment-water sulfide fluxes in the mid-bay ${ }^{33,34}$, clearly support the accumulation of sulfide observed in August 2013 (Fig. 2f).

Subsurface pH minimum due to oxidation of reduced chemicals. Repeated vertical profiles during both summers revealed a consistent $\mathrm{pH}$ minimum below the surface mixed layer at our focused study station, a deep site in the upper part of the mid-bay. Salinity profiles at this site (Fig. 2a) combined with a time series of wind speed indicate a physical mixing event before our first sampling on August 9, 2013. Stratification quickly re-established when wind speed reduced and the wind direction switched from favoring mixing to favoring stratification (Supplementary Fig. 6a, b). Total alkalinity (TA) and DIC were lower in the surface, but became higher in the bottom water (Fig. 2b, c). Dissolved $\mathrm{O}_{2}$ was at saturation or supersaturation in the surface due to gas exchange and biological production and was not detectable below 10-15 $\mathrm{m}$ depths due to respiration (Fig. 2d).

On day 1 , the mixed layer depth was still as deep as $15-18 \mathrm{~m}$, but within 2 days, it shoaled to $10 \mathrm{~m}$ (Fig. 2a). Following this dynamic change, the $\mathrm{O}_{2}$ penetration depth changed from about $15 \mathrm{~m}$ on day 1 to about $10 \mathrm{~m}$ on days 3-5 (Fig. 2d). Simultaneously, water column $\mathrm{pH}\left(25^{\circ} \mathrm{C}\right.$ and NBS scale) decreased greatly over this period (Fig. 2e). For example, at the depth of $6 \mathrm{~m}, \mathrm{pH}$ decreased from nearly 8.0 on day 1 to $\sim 7.5$ on days $3-5$. A pH minimum $(7.35 \pm 0.03)$ occurred at $11-13 \mathrm{~m}$ depth in the low $\mathrm{O}_{2}$ zone $\left(<10 \mu \mathrm{mol} \mathrm{kg}^{-1}\right)$, below which $\mathrm{pH}$ increased slightly and then became constant at $7.45 \pm 0.02$. This $\mathrm{pH}$ minimum and the associated rapid $\mathrm{pH}$ decrease above it within a short period of $<2$ days have not been previously documented, although large $\mathrm{pH}$ changes were observed or expected in many strongly productive or stratified shallow water systems ${ }^{35-37}$. Such dramatic decreases in both $\mathrm{O}_{2}$ and $\mathrm{pH}$ over just 2 days could likely put the biological system under stress ${ }^{38}$. This $\mathrm{pH}$ minimum was also observed in August 2014, though water column $\mathrm{O}_{2}$ and $\mathrm{pH}$ profiles in August 2014 were relatively stable before and during the 5-days cruise, as wind speeds were less strong and less variable than those of the 2013 (Supplementary Fig. $7 \mathrm{a}, \mathrm{b}$ ), the oxycline (where $\mathrm{O}_{2}$ decreases rapidly) and the $\mathrm{pH}$ minimum were even sharper and shallower, and bottomwater pH, DIC and TA were lower in 2014 than 2013 (Supplementary Fig. 8).

We suggest the oxidation of reduced chemicals is responsible for the $\mathrm{pH}$ minimum in the low $\mathrm{O}_{2}$ zone and the rapid $\mathrm{pH}$ decrease above it where declining $\mathrm{O}_{2}$ gradients were steepest (Fig. 2e). The coupling between acid-base and redox chemistry is described by the following formula:

$$
\begin{gathered}
\mathrm{H}_{2} \mathrm{~S}+2 \mathrm{O}_{2}=2 \mathrm{H}^{+}+\mathrm{SO}_{4}^{2-} \\
\mathrm{NH}_{4}^{+}+2 \mathrm{O}_{2}=2 \mathrm{H}^{+}+\mathrm{NO}_{3}^{-}+\mathrm{H}_{2} \mathrm{O} \\
\mathrm{Mn}^{2+}+0.5 \mathrm{O}_{2}+\mathrm{H}_{2} \mathrm{O}=2 \mathrm{H}^{+}+\mathrm{MnO}_{2} \\
\mathrm{Fe}^{2+}+0.25 \mathrm{O}_{2}+1.5 \mathrm{H}_{2} \mathrm{O}=2 \mathrm{H}^{+}+\mathrm{FeOOH}
\end{gathered}
$$

In August 2013, because of the strong mixing event prior to our cruise, the total concentration of $\mathrm{H}_{2} \mathrm{~S}$ was only $5 \mu \mathrm{mol} \mathrm{kg} \mathrm{m}^{-1}$ at the $20 \mathrm{~m}$ depth on day 1 , but it rapidly increased to $30-40 \mu \mathrm{mol} \mathrm{kg}{ }^{-1}$ on days 3-5 when the water column was restratified (Fig. $2 \mathrm{f})^{39}$. Oxidation of other reduced chemicals accumulating in the bottom water could also have contributed to the formation of the $\mathrm{pH}$ minimum. $\mathrm{NH}_{4}{ }^{+}$concentration measured near our site was $15-20 \mu \mathrm{mol} \mathrm{kg}^{-1}$ at $20 \mathrm{~m}$ (Supplementary Fig. 9). Also, during days 3-5, bottom water $\left[\mathrm{Mn}^{2+}\right]$ and $\left[\mathrm{Fe}^{2+}\right]$ became as high as 7 and $2 \mu \mathrm{mol} \mathrm{kg}^{-1}$, respectively ${ }^{39}$. When these reduced species (total concentration $\sim 60 \mu \mathrm{mol} \mathrm{kg}{ }^{-1}$ ) were mixed upward into oxygenated water, they were oxidized, hydrogen ions were generated, TA was decreased and thus the water became more acidified (see Eqs. (1)-(4)). However, we recognize the oxidation of reduced species are often complex involving many intermediate steps and side products ${ }^{40}$ and could have different $\mathrm{H}^{+}$ production ratios.

It has been shown that oxidation of $\mathrm{H}_{2} \mathrm{~S}$ by $\mathrm{O}_{2}$ is sufficiently slow that $\mathrm{H}_{2} \mathrm{~S}$ can be brought near to the surface during vigorous mixing events and lead to fish kills in coastal waters $20,36,41$. Similarly, ammonia oxidation is not instantaneous ${ }^{12}, 17,41$. We suggest that the slow oxidation kinetics and rapid mixing facilitate the transport of reduced species and can subsequently result in acidification of the oxygenated near- and sub-surface waters, potentially resulting in a negative impact on aquatic organisms $^{38}$. If, for example, one volume of bottom water of 60 $\mu \mathrm{mol} \mathrm{kg}{ }^{-1}$ of reduced chemicals is mixed with one volume of sufficiently oxygenated water, the resulting mixed water has the total concentration of the reduced chemicals halved to $30 \mu \mathrm{mol} \mathrm{kg}$ -1 , and eventually $\sim 60 \mu \mathrm{mol} \mathrm{kg} \mathrm{kg}^{-1}$ of acid (or $-\Delta \mathrm{TA}$ ) would be generated due to the oxidation of the reduced chemical species (Eqs. (1)-(4)). Based on CO2SYS simulations, the predicted $\mathrm{pH}$ decrease due to these oxidation reactions can be up to $0.20 \mathrm{pH}$ units in Chesapeake Bay waters, although other mixing ratios and incomplete reactions due to slow kinetics may generate less of a $\mathrm{pH}$ decrease (Methods). This $\mathrm{pH}$ decrease is substantial and is consistent with our observations (Fig. 2e; also see a model simulation of TA, DIC, $\mathrm{O}_{2}$, and $\mathrm{pH}$ evolving loci below). Note that while the size and location of this $\mathrm{pH}$ minimum may vary depending on the strength of the physical mixing and $\left[\mathrm{H}_{2} \mathrm{~S}\right]$ in the bottom water, it occurs whenever bottom-water anoxia exists regardless of whether a prior severe mixing event has occurred as in our 2013 study, because moderate mixing occurs constantly in the bay (Supplementary Fig. 7). 
a

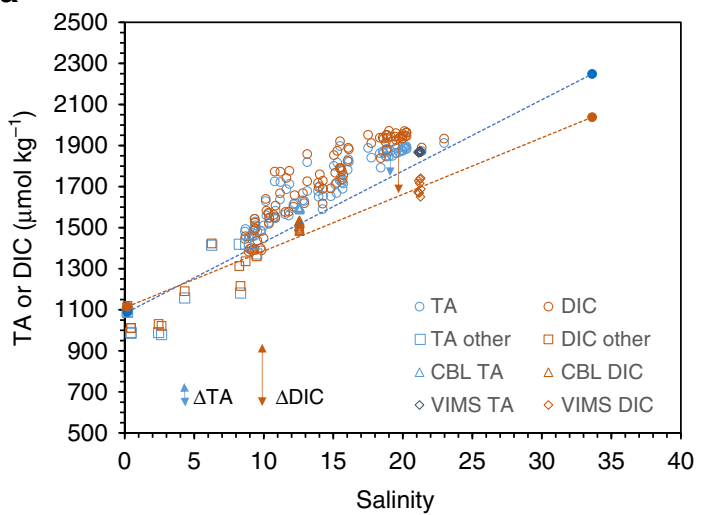

b

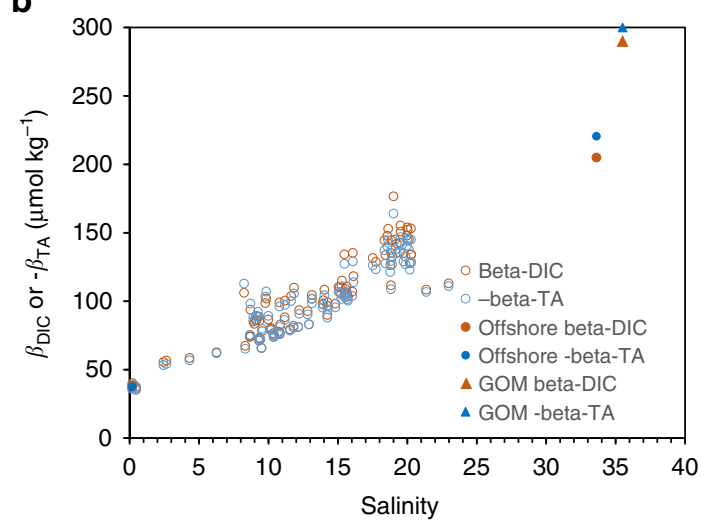

Fig. 3 Total alkalinity and dissolved inorganic carbon as well as buffer factor distributions against salinity in August 2013. a Total alkalinity (TA) and dissolved inorganic carbon (DIC) and $\mathbf{b}$ buffer factors (see definitions in Eqs. (6) and (7)). Most data were collected at the focused study site over a 5-day period, as marked in Fig. 1 (station 858). Those marked as TA other or DIC other were collected in waters between station 858 and the Chesapeake-Delaware Canal in the upper bay (Fig. 1). Data were also collected in the mid- and lower-bays at the CBL dock and the VIMS dock shortly after the main cruise

In sediment porewater, a $\mathrm{pH}$ minimum was reported at and above the $\mathrm{O}_{2}$ penetration depths as a result of oxidation of reduced chemicals, which diffused upward from deeper, anoxic depths ${ }^{42,} 43$ and was predicted by sediment diagenetic models ${ }^{44}, 45$. Such a $\mathrm{pH}$ minimum was also seen in low $\mathrm{O}_{2}$ waters of permanently stratified and anoxic deep basins including the Baltic Sea ${ }^{13}, 17$, the Black Sea ${ }^{18,19}$, the Framvaren Fjord ${ }^{21}$, the Hunnbunn Fjord ${ }^{20}$, and the Cariaco Basin ${ }^{22}$ though no one has pointed out this phenomenon except Yao and Millero ${ }^{21}$ who commented that "the low $\mathrm{pH}$ is difficult to explain". The $\mathrm{pH}$ minimum is an interesting feature that results from the decrease in TA:DIC ratio due to acid production during oxidation of reduced chemicals when encountering free $\mathrm{O}_{2}$ due to vigorous physical mixing. To our knowledge, this is the first time that such a $\mathrm{pH}$ minimum has been reported and properly interpreted in the water column. We predict that the $\mathrm{pH}$ minimum should occur in all oceanic systems that have seasonally or permanently occurring oxic-anoxic boundaries, including the above mentioned cases as well as in the dead-end canals of Delaware Inland Bays ${ }^{36}$, Lake Grevelingen (the Netherlands) ${ }^{12}$, the Saanich Inlet ${ }^{46}$, and estuaries and bays elsewhere ${ }^{17}, 20$. We further argue that the $\mathrm{pH}$ minimum is likely more dynamic in seasonally anoxic coastal systems than permanently anoxic deep basins, due to the shallower water depth and higher frequency of physical disturbances. Physical disturbances such as winds and tides occur regularly in the Chesapeake Bay (Supplementary Fig. 7a, b) and other seasonally stratified coastal waters ${ }^{12}, 36$. Therefore, their chemical and biological consequences, in the context of coastal $\mathrm{OA}$ and deoxygenation, deserve further attention.

Geochemical drivers and carbonate dissolution. To separate biological processes from physical mixing and to explore the biogeochemical control mechanisms in a broader context, we examine TA and DIC vs. salinity relationships at this site together with data from other areas of the bay and the river and offshore endmembers (Fig. 3a). Between the river and ocean endmembers, as expected, TA and DIC increased with salinity. However, at our focused study station, all subsurface and bottom-water samples were located well above the mixing lines, indicating net release of $\mathrm{CO}_{2}$ and accumulation of DIC and TA. In addition, both DIC and TA data collected at the Chesapeake Biological Laboratory (CBL) dock, downstream of our focused study site at the lower end of the mid-bay, were also above the mixing lines. Those from the Virginia Institute of Marine Science (VIMS) dock, farther downstream near the bay mouth, however, showed the least enrichment relative to the conservative mixing lines. We also calculated the acid-base buffer factors from TA, DIC, and nutrients $\left(\mathrm{PO}_{4}{ }^{3-}, \mathrm{H}_{2} \mathrm{~S}\right.$, and $\left.\mathrm{NH}_{4}{ }^{+}\right)$(Methods). It is clear the bay waters are poorly buffered as indicated by their much lower buffer factors compared to offshore waters here and elsewhere (Fig. 3b; also see next section for definitions and explanations).

TA is usually a good conservative tracer of river-ocean mixing within an estuary because it is not influenced by $\mathrm{CO}_{2}$ addition and removal. Because TA and DIC share a common major component $\left(\mathrm{HCO}_{3}{ }^{-}\right)$, deviations of DIC from the nearly conservative behavior defined by $\mathrm{TA}$ and salinity provide a measure of biological use or release of $\mathrm{CO}_{2}{ }^{47}$. Bottom waters in the Chesapeake Bay, however, are conspicuously different from this general geochemical behavior normally encountered in oxygenated or moderately low oxygen environments $8,9,47$. DIC not only show a large enrichment against the conservative mixing line, but TA is also substantially enriched; with the excess DIC and TA reaching $275.3 \pm 59.5$ and $167.3 \pm 54.2 \mu \mathrm{mol} \mathrm{kg}^{-1}$ respectively (Fig. 3a, Methods).

In any estuary, the most important internal sources of TA and DIC are aerobic respiration (AR), SR, and carbonate dissolution (CD) ${ }^{12,13,21,45}$ (Fig. 4a, Table 2). Because each of these processes has a distinctly different $\Delta \mathrm{TA}$ to $\triangle \mathrm{DIC}$ ratio and involves a different $\mathrm{pH}$ change (Table 2), $\Delta \mathrm{TA}: \Delta \mathrm{DIC}$ ratio and $\mathrm{pH}$ change become diagnostic of the geochemical processes. Based on the mixing line prediction, we can calculate the initial DIC and TA values at salinity $(S)=10 \mathrm{~g} \mathrm{~kg}^{-1}$ for surface water and $S=20 \mathrm{~g} \mathrm{~kg}^{-1}$ for bottom water. From the solubility constants we can also determine the initial concentrations of $\mathrm{O}_{2}$ in $S=10$ and $20 \mathrm{~g} \mathrm{~kg}^{-1}$ waters. Assuming the bottom water starts with a fully saturated dissolved $\mathrm{O}_{2}$, we can then derive DIC and TA generations and $\mathrm{pH}$ change for each step (Table 2 ). In this poorly buffered water (Fig. 3b), the complete use of $\mathrm{O}_{2}$ solely for AR would drive bottom-water TA and $\mathrm{pH}$ lower than the observed values (Fig. 4a, b). Sulfate reduction and $\mathrm{CaCO}_{3}$ dissolution must then be invoked to explain the observed $\mathrm{TA}$ and $\mathrm{pH}$. The effects of $\mathrm{SO}_{4}{ }^{2-}$ reduction on TA and DIC can be estimated from the observed $\left[\mathrm{H}_{2} \mathrm{~S}\right]$ (Table 2) and the rest is made up by $\mathrm{CaCO}_{3}$ dissolution (Methods). We envision that these three processes can occur either sequentially (Table 2) or simultaneously when $\mathrm{O}_{2}$, $\mathrm{pH}$, carbonate mineral saturation state are sufficiently low. While the sequential pathway simulates the general patterns of the TA and DIC relationship (Fig. $4 \mathrm{a}$ ) and the $\mathrm{pH}$ and $\mathrm{O}_{2}$ relationship 

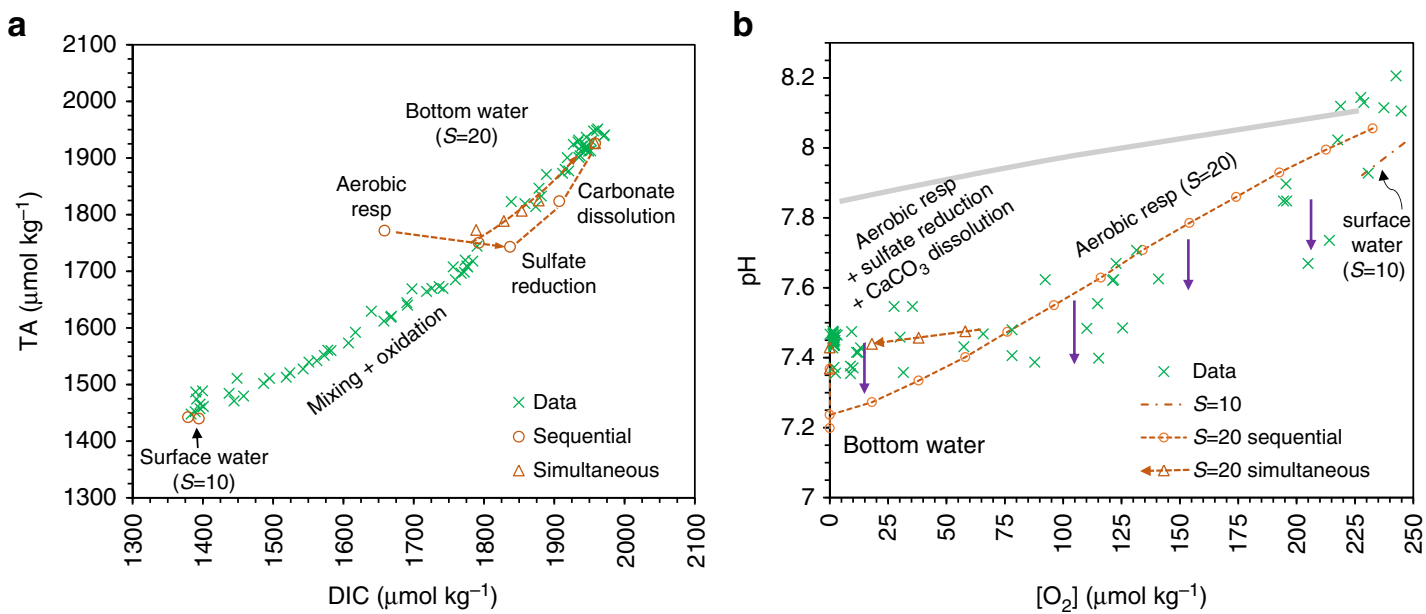

Fig. 4 Model simulations of the evolution of total alkalinity, dissolved inorganic carbon, $\mathrm{pH}$, and $\mathrm{O}_{2}$ during biogeochemical processes. a Total alkalinity ( $T A$ ) and dissolved inorganic carbon $(\mathrm{DIC})$ relationship and $\mathbf{b} \mathrm{pH}\left(25^{\circ} \mathrm{C}\right.$ and $\mathrm{NBS}$ scale) and $\left[\mathrm{O}_{2}\right]$ relationship. The biogeochemical pathway, or TA and DIC loci, includes aerobic respiration $(A R)$, sulfate reduction $(S R)$ and $\mathrm{CaCO}_{3}$ dissolution $(C D)$. Predicted $\mathrm{pH}$ or $\mathrm{TA}$ values are provided together with observed pH or TA (calculated from pH and DIC data from August 2013). Both sequential (open circles) and simultaneous (triangles) pathways are presented. Purple arrows represent acidification generated by oxidation of reduced chemicals $\left(\mathrm{H}_{2} \mathrm{~S}\right)$. The light shaded line at the top indicates the $\mathrm{pH}^{\mathrm{H}}$ and $\left[\mathrm{O}_{2}\right]$ relationship from the Gulf of Mexico reflecting aerobic respiration

(Fig. 4b) reasonably well, it appears that $\mathrm{CaCO}_{3}$ dissolution must have proceeded and occurred simultaneously with AR and SR as the simultaneous pathway simulates the observation better (Fig. $4 \mathrm{a}, \mathrm{b}$ ) and as is justified by the very low aragonite carbonate saturation state once more than $50 \%$ of $\mathrm{O}_{2}$ is consumed (Table 2).

From the above simulations, we conclude that up to $\sim 70 \%$ of the bottom-water TA production comes from $\mathrm{CaCO}_{3}$ dissolution, which raises bottom-water $\mathrm{pH}$ from expected 7.25 to 7.45 and provides an important buffer mechanism in bottom waters (Methods). It has been reported that eutrophication led to lower $\mathrm{pH}$ in the polyhaline $\left(S>18 \mathrm{~g} \mathrm{~kg}^{-1}\right)$ part of the bay between 1985 and $2008^{26}$. Based on our data and model simulations, we suggest that eutrophication in the bay has led to more $\mathrm{O}_{2}$ consumption, $\mathrm{SO}_{4}{ }^{2-}$ reduction, $\mathrm{pH}$ decrease, and dissolution of $\mathrm{CaCO}_{3}$ shells and abiotic minerals in subsurface and bottom waters, consequently leading to possibly more TA and DIC export to the coastal ocean.

While shellfish calcification can represent a significant store of $\mathrm{CaCO}_{3}$ in the Chesapeake Bay ${ }^{26,48}$, much of the CD present in the current study likely also comes from abiotic precipitation in surface waters, a mechanism noted before in the Loire estuary ${ }^{49}$. The extent of $\mathrm{CD}$ in deep waters estimated here could be supported by independently estimated $\mathrm{CaCO}_{3}$ production in surface waters from deviations from conservative mixing (Supplementary Fig. 10) ${ }^{48}$, which is consistent with the TA deficit observed here in low-salinity surface waters (Fig. 3a). While the precipitation may largely be driven by seasonal dynamics in primary production enhanced by estuarine eutrophication $^{49}$, importantly, current and future increasing atmospheric $\mathrm{CO}_{2}$ due to fossil fuel production may lower surface water carbonate saturation state enough to decrease mineral formation and thus delivery below the pycnocline. If so, the bay's deep water would have a reduced capacity to neutralize metabolically generated $\mathrm{CO}_{2}$, further enhancing eutrophication driven acidification.

Another important metabolic pathway is denitrification which uses $\mathrm{NO}_{3}{ }^{-}$as the oxidant for organic matter decomposition ${ }^{50,51}$. Note that $\left[\mathrm{NO}_{3}{ }^{-}\right]$is generally low in the mid-bay $\left(<1 \mu \mathrm{mol} \mathrm{kg}{ }^{-1}\right)$. However, denitrification is often coupled to nitrification at the sediment water interface. System-wide integrated denitrification rate has been estimated to be about $70 \mu \mathrm{mol} \mathrm{m}{ }^{-2} \mathrm{~h}^{-1}$ in the
Chesapeake Bay (summer time) ${ }^{52}$, although other estimations are lower. Taking this value as the upper end, we estimate that denitrification can contribute to a DIC production of up to 17 $\mu \mathrm{mol} \mathrm{kg}{ }^{-1}$ and TA production of up to $16 \mu \mathrm{mol} \mathrm{kg}^{-1}$ in a $10 \mathrm{~m}$ bottom-water column and over a 100-day period. This amount is only up to about $8 \%$ of the total TA production in the bottom water observed here. Finally, while organic matter decomposition using metal oxides as oxidants is important intermediate steps for biogeochemical cycles, the contributions to alkalinity production must be lower in the bay as recycled $\left[\mathrm{Mn}^{2+}\right]\left(<7 \mu \mathrm{mol} \mathrm{kg}{ }^{-1}\right)$ and $\left[\mathrm{Fe}^{2+}\right](<2 \mu \mathrm{mol} \mathrm{kg}-1)^{39}$ are much lower than the observed TA production in the bottom water; a conclusion similar to that derived in the Baltic Sea ${ }^{13}, 21$.

\section{Discussion}

The buffering capacity reflects the marine carbonate system's ability to resist changes in $\mathrm{pH}\left(\right.$ or $\left.p \mathrm{CO}_{2}\right)$ when DIC and/or TA are altered by physical and biogeochemical processes and when relevant thermodynamic constants are altered by temperature $(T)$ and salinity $(S)$ changes ${ }^{53-58}$. Mathematically, an aquatic system's ability to resist $\mathrm{pH}$ change can be deconstructed into its sensitivity to changes in $T, S$, DIC, and TA.

$$
\begin{aligned}
& \mathrm{dpH}= \\
& \left(\frac{\partial \mathrm{pH}}{\partial T}\right) \mathrm{d} T+\left(\frac{\partial \mathrm{pH}}{\partial S}\right) \mathrm{d} S+\left(\frac{\partial \mathrm{pH}}{\partial \mathrm{DIC}}\right) \mathrm{dDIC}+\left(\frac{\partial \mathrm{pH}}{\partial \mathrm{TA}}\right) \mathrm{dTA}+\ldots
\end{aligned}
$$

Here the first and second terms represent the effects of change in thermodynamic constants as a function of $T$ and $S$. The third term reflects the $\mathrm{pH}$ change when DIC is added while keeping $T, S$, and TA constant and the fourth term reflects the $\mathrm{pH}$ change when a strong acid $\left(\mathrm{H}^{+}\right.$or $\left.-\Delta \mathrm{TA}\right)$ is added while keeping $T, S$, and DIC constant. The slopes in the third and fourth terms are directly related to the buffer factors $\beta_{\mathrm{DIC}}$ and $\beta_{\mathrm{TA}}$ defined before ${ }^{53,54}$ with

$$
\beta_{\text {DIC }}=-(2.3 \times \partial \mathrm{pH} / \partial \mathrm{DIC})^{-1}
$$


Table $2 \mathrm{O}_{2}$ consumption and DIC and TA production during sequential aerobic respiration, sulfate reduction and carbonate mineral dissolution in bottom waters 45,83

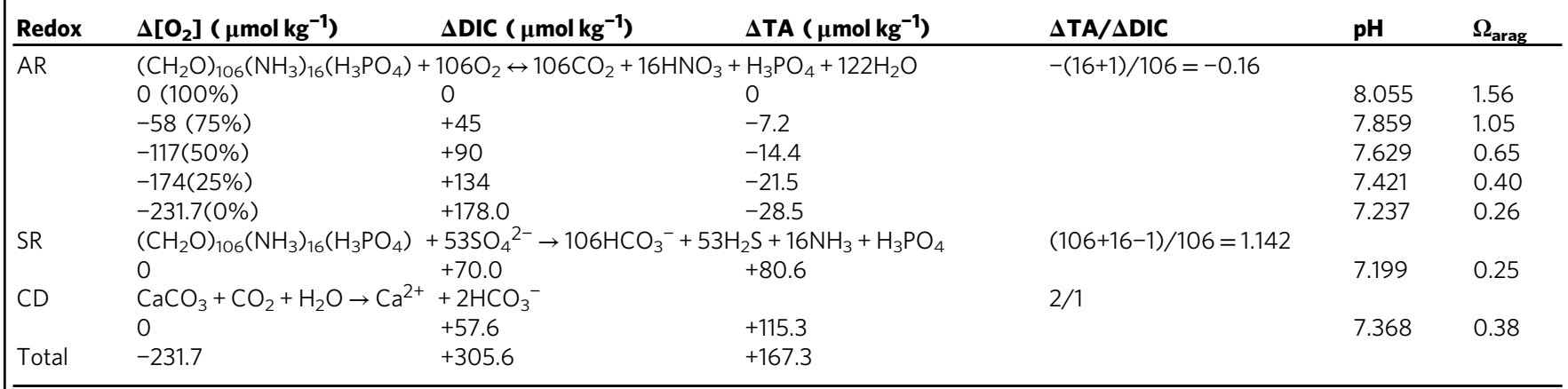

$\mathrm{AR}$, aerobic respiration; $\mathrm{CD}$, carbonate dissolution; DIC, dissolved inorganic carbon; SR, sulfate reduction; $\mathrm{TA}$, total alkalinity. The last columns listed the expected pH and aragonite mineral saturation state $\left(\Omega_{\text {arag }}\right.$ ) values at the end of each step. $\mathrm{pH}$ and $\Omega_{\text {arag }}$ values are also calculated at the initial and mid-points of $\mathrm{O}_{2}$ consumption (or \% of $\mathrm{O}_{2}$ saturation). For simultaneous reactions at low pH and $\Omega_{\text {arag, }}$ see the text. The calculation steps and results are detailed in the Methods. Note for a more stable carbonate mineral, calcite, $\Omega_{\text {calcite }}=1.5 \times \Omega_{\text {arag }}$

and

$$
\beta_{\mathrm{TA}}=-(2.3 \times \partial \mathrm{pH} / \partial \mathrm{TA})^{-1}
$$

In estuarine conditions, because $\beta_{\mathrm{DIC}}$ and $\beta_{\mathrm{TA}}$ are similar in magnitude ${ }^{54}$ (also see Fig. $3 \mathrm{~b}$ ), the overall contribution to acidification or $\mathrm{pH}$ decrease is largely decided by changes in DIC and TA during physical and biogeochemical processes (e.g., at constant $T$ and $S$ ) and also by the initial buffering capacity (e.g., at variable $T$ and $S$ ).

The $\mathrm{pH}$ and $\left[\mathrm{O}_{2}\right]$ relationship in Chesapeake Bay waters differs greatly from that observed in northern Gulf of Mexico (nGOM) waters (shaded line in Fig. $4 \mathrm{~b})^{9}$. It appears that Chesapeake Bay waters are more vulnerable to both anthropogenic $\mathrm{CO}_{2}$ and biological induced acidifications because they have a lower buffering capacity than that of the offshore waters, in particular, in the nGOM as TA and DIC are lower in the Susquehanna River and US eastern margin waters than those of the Mississippi River and nGOM seawater (Figs. $3 \mathrm{~b}, 4 \mathrm{~b}$ and $5 \mathrm{a}$ ) $9,59,60$. However, our simulations and those of the previous studies ${ }^{12,53-57}$ suggest that lower buffering capacity itself does not necessarily lead to low $\mathrm{pH}$ (Fig. 5a); rather, it allows a much greater $\mathrm{pH}$ decrease when other sources of $\mathrm{CO}_{2}$ or strong acids are added (Fig. 5b). Similar amounts of AR (Table 2) would lead to a $\mathrm{pH}$ decrease of only 0.4 units in the strongly buffered nGOM waters whereas a larger decrease of nearly 0.8 units would occur in the poorly buffered Chesapeake Bay waters at the present day conditions (at $S=34$ and $20 \mathrm{~g} \mathrm{~kg}^{-1}$, respectively, Figs. $4 \mathrm{~b}$ and $5 \mathrm{c}$ ).

While the $\mathrm{OA}$ signal due to $\mathrm{CO}_{2}$ uptake in the open ocean regions is similar across middle and lower latitudes, the manifestation of this anthropogenic $\mathrm{CO}_{2}$ signal through ocean-river mixing in estuaries is dependent on the river TA and DIC values, which are highly variable among the world's rivers ${ }^{61}$, and whether $\mathrm{CO}_{2}$ is also introduced via microbial respiration ${ }^{11,60}$. Due to the very high river TA and DIC and the resulting strong buffering capacity over the entire salinity range in the Mississippi River impacted coastal waters, $\mathrm{pH}$ change due to $\mathrm{OA}$ is proportional to the open ocean OA source signal and salinity and decreases toward zero salinity (Fig. 5a) ${ }^{9}, 60,62$. In the Chesapeake Bay where average river TA, DIC, and buffering capacity are low, however, the oceanic OA signal is amplified in the low and middle salinity zone. Here the combination of reduced buffering capacity (with decreasing salinity) and a still sufficiently strong open ocean OA signal generates a minimum buffer zone ${ }^{60}$ and thus a Maximum Estuarine Acidification Zone (MEAZ) (Fig. 5c). The existence of a MEAZ and its salinity range depend not only on the river TA value, but also the TA:DIC ratio ${ }^{60}$. When $\mathrm{CO}_{2}$ addition from AR increases from 0 to 100 and finally to $\sim 200 \mu \mathrm{mol} \mathrm{kg}^{-1}$ (or 0 to roughly half or to a full $\mathrm{O}_{2}$ consumption depending on the salinity and temperature), the minimum buffer zone shifted from salinity $\sim 4$ to $\sim 13$ (Fig. 5a) and finally to $\sim 23$ (Fig. 5b) ${ }^{60}$. Note that local $\mathrm{CO}_{2}$ uptake, carbonate mineral dissolution and SR are not included in this discussion (Fig. 5) and would further modify the estuarine buffering capacity as they would modify the TA to DIC ratio in estuarine waters (Table 2, Figs. 3b, $4 a, b$ ).

Below we further discuss the effects of anthropogenic $\mathrm{CO}_{2}$ and biological $\mathrm{CO}_{2}$ and acid additions on estuarine $\mathrm{pH}$ buffering capacity $^{53}, 54$. The marine carbonate system has a minimum buffering or maximum $\mathrm{pH}$ change point when DIC increases approximately equal to that of TA (or TA:DIC $\approx 1$ ) where $\left[\mathrm{CO}_{2}\right]$ $=\left[\mathrm{CO}_{3}{ }^{2-}\right]+\left[\mathrm{B}(\mathrm{OH})_{4}{ }^{-}\right]$(if we ignore all other weak acid-base species). At this point, any addition or removal of $\mathrm{CO}_{2}$ or acids will result in a maximum $\mathrm{pH}$ decrease or increase. Because DIC is slightly higher than or nearly equal to TA in rivers ${ }^{47,62,63}$ and is lower than TA in seawater, there may exist a small crossover of DIC and TA at the very low-salinity zone. A peculiar $\mathrm{pH}$ minimum occurring in the low-salinity zone of estuaries is related to this mixing feature as was noticed a long time ago in both closed $^{64}$ and open ${ }^{65}$ system simulations. Furthermore, how $\mathrm{CO}_{2}$ is added to the estuarine waters affect how the crossover point will move. First we contend anthropogenic $\mathrm{CO}_{2}$ does not directly add to the high $p \mathrm{CO}_{2}$ river water but is mixed into the estuary via river-ocean mixing ${ }^{60}$. In contrast, respiratory $\mathrm{CO}_{2}$ is nearly equally added to the bottom water based on $\mathrm{O}_{2}$ consumption regardless of the mixing index or salinity (except that $\mathrm{O}_{2}$ solubility increases when salinity decreases, but it is a small correction). In Fig. 6, we summarize several scenarios illustrating how the crossover point of the TA and DIC to salinity lines or the point of TA:DIC ratio $=1$ moves along the TA-salinity line. Adding anthropogenic $\mathrm{CO}_{2}$ to the seawater endmember would move this crossover point to only a slightly higher salinity. Adding biological $\mathrm{CO}_{2}$ (for example $100 \mu \mathrm{mol} \mathrm{kg}^{-1}$ ) to both the river and ocean endmembers would, however, shift the DIC line to a much higher position (parallel to the original line) creating a crossover point located at a salinity substantially higher than the original one. Finally the combined effect of anthropogenic $\mathrm{CO}_{2}$ and biological $\mathrm{CO}_{2}$ from respiration moves the crossover point to an even higher salinity. These crossover points are consistent with the progressive shift of the minimum buffer factor $\left(\beta_{\text {DIC }}\right)$, the $\mathrm{pH}$ minimum, and the maximum acidification zone $(-\Delta \mathrm{pH})$ presented in Fig. 5. However there appears a difference in the location (salinity) between the minimum buffer factor $\left(\beta_{\text {DIC }}\right)$ and 

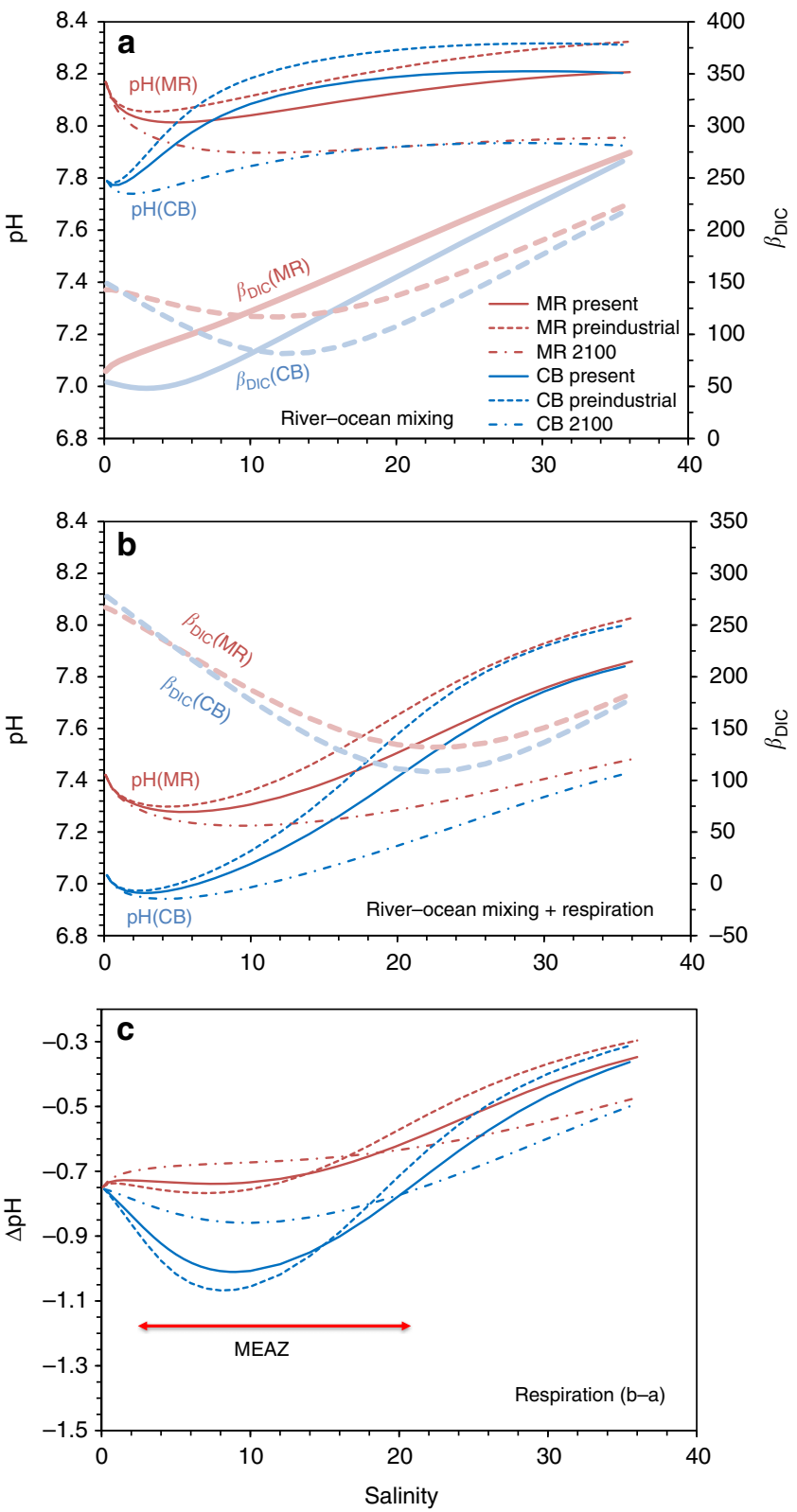

Fig. 5 Simulations of $\mathrm{pH}$ and $\mathrm{pH}$ decrease and the evolution of the buffer factor $\beta_{\mathrm{DIC}}$ in Chesapeake Bay (CB) waters and Mississippi River (MR) coastal waters. a pH curves (thin lines) during estuarine mixing under three scenarios (preindustrial era, present day, and year 2100). Buffer factor $\beta_{\text {DIC }}$ for the present day condition (thick solid lines) and the present day condition plus $100 \mu \mathrm{mol} \mathrm{kg}^{-1}$ (thick dashed lines) are also presented for both estuaries. b $\mathrm{pH}$ curves and $\beta_{\mathrm{DIC}}$ curves plus full $\mathrm{O}_{2}$ consumption (respiration) during estuarine mixing. (c) $\mathrm{pH}$ decrease $(-\Delta \mathrm{pH})$ as a result of full $\mathrm{O}_{2}$ consumption during estuarine mixing (a difference between $\mathbf{b}$ and $\mathbf{a}$ ). The red arrows represents the Maximum Estuarine Acidification Zone (MEAZ). Note that $\beta_{\text {DIC }}$ presented here does not match that from the real data (Fig. 3b) at low salinities as a stratified and $\mathrm{O}_{2}$ depleted state does not exist for the very low salinity part of the Chesapeake Bay

the maximum acidification $(-\Delta \mathrm{pH})$. This is because $\Delta \mathrm{pH}$ represents the accumulative $\mathrm{pH}$ change between an end point and a beginning point while the buffer factor reflects the $\mathrm{pH}$ sensitivity at a specific point if additional DIC is added to the system.

In summary, large estuarine water bodies, exemplified by the Chesapeake Bay, are particularly vulnerable to the anthropogenic $\mathrm{CO}_{2}$ and eutrophication-induced coastal OA. In this paper we

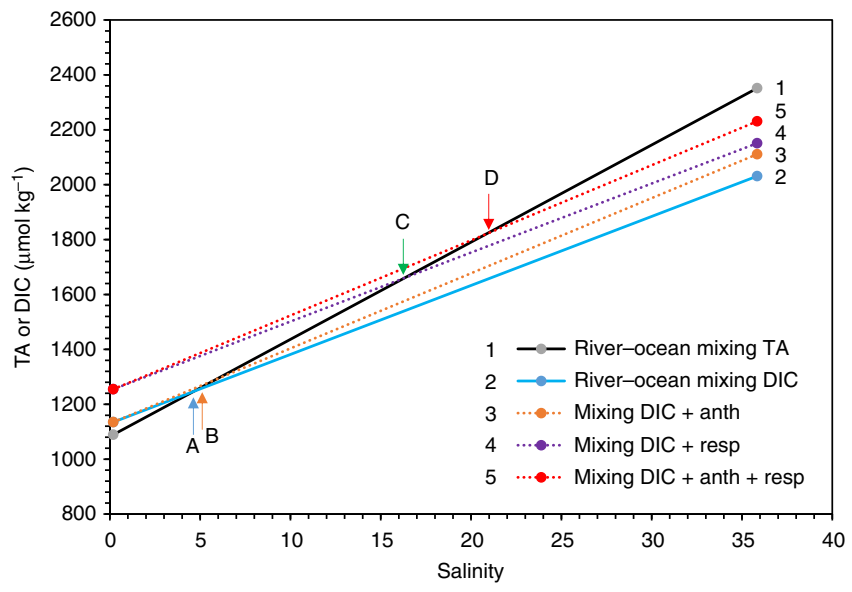

Fig. 6 Estuarine TA or DIC mixing lines between the river and ocean endmembers with additional $\mathrm{CO}_{2}$ added in from anthropogenic sources and respiration. Line 1 is river-ocean mixing of TA, line 2 is river-ocean mixing of $\mathrm{DIC}$, line 3 is mixing DIC plus anthropogenic $\mathrm{CO}_{2}$ addition, line 4 is mixing DIC plus respiratory $\mathrm{CO}_{2}$ addition, and line 5 is mixing DIC plus both anthropogenic and biological $\mathrm{CO}_{2}$ additions. The crossover points are river-ocean mixing lines of TA with $A$ river-ocean mixing lines of DIC, $B$ mixing plus anthropogenic $\mathrm{CO}_{2}, \mathrm{C}$ mixing plus $\mathrm{CO}_{2}$ from respiration, and $\mathrm{D}$ mixing plus $\mathrm{CO}_{2}$ from both $\mathrm{B}$ and $\mathrm{C}$

emphasize that subsurface $\mathrm{H}_{2} \mathrm{~S}$ oxidation ( $0.2 \mathrm{pH}$ units) and local surface $\mathrm{CO}_{2}$ uptake ( $\sim .1 \mathrm{pH}$ units) work together with known organic matter respiration and the open-ocean OA source signal to drive substantial acidification and $\mathrm{CaCO}_{3}$ dissolution in estuarine subsurface waters. Currently, acidification due to $\mathrm{CO}_{2}$ input from $\mathrm{AR}$ (up to $0.8 \mathrm{pH}$ units) in the bay exceeds that from the atmospheric $\mathrm{CO}_{2}$ increase in the open ocean $(\sim 0.1 \mathrm{pH}$ units in surface waters and the signal is mixed into estuaries proportional to salinity) and local estuarine uptake; but towards the end of this century the latter will approach or exceed the former and the synergy between them will also increase. In addition, future increasing atmospheric $\mathrm{CO}_{2}$ due to fossil fuel production may lower carbonate saturation state enough to decrease mineral formation in surface water and thus delivery below the pycnocline, where we have currently demonstrated that $\mathrm{CaCO}_{3}$ dissolution offsets a significant proportion of the metabolic $\mathrm{CO}_{2}$ effect on acidification. We further recognize that natural and anthropogenic acidification mechanisms most relevant to estuarine acidification are characterized by various time scales. They range from nearly instantaneous for acid-base equilibrium ${ }^{66}$, to minutes for $\mathrm{CO}_{2}$ hydration ${ }^{66}$, and to minutes to hours for $\mathrm{H}_{2} \mathrm{~S}$ oxidation ${ }^{36,41,67}$. In contrast, time scales for physical mixing are on the order of tidal or less, to daily and seasonal ${ }^{30,31}$, 68 while local $\mathrm{CO}_{2}$ uptake from the atmosphere and its accumulation in the water column and acidification of the bottom water as well as pelagic and benthic respirations operate over tidal to seasonal scales ${ }^{12,13,35,37,69}$. Although anthropogenic changes in external forcing due to variability in river and ocean endmembers may also have a seasonal component, decadal and centennial variation is more important $5,35,70,71$. This mosaic of processes with different time and space scales poses a great challenge in our ability to understand and predict coastal OA.

\section{Methods}

Site and cruise descriptions. The Chesapeake Bay is the largest estuary in the US The August 2013 survey started from the upper estuary near the Susquehanna River mouth (Fig. 1a). The upper and middle Chesapeake Bay were surveyed during 9-14 August 2013 by RV Hugh R. Sharp. The water column survey focused mainly at one site south of the Bay Bridge ( $\left.38^{\circ} 58.8 \mathrm{~N}, 76^{\circ} 22 \mathrm{~W}\right)$, where a field study 
of redox chemistry ${ }^{39}$ and water column inorganic carbon and $\mathrm{pH}$ were carried out. We consider this site as the up end of the mid-bay. We repeatedly sampled the water column at high slack tide and low slack tide. During this 5-day survey, an excursion was made south to the middle bay near Solomons Island. After the completion of the cruise, we set up two 24-h dockside measurements, one at the dock of the Chesapeake Biological Laboratory (CBL; $\left.38.317317^{\circ} \mathrm{N}, 76.450980^{\circ} \mathrm{W}\right)$ on Solomons Island near the southern end of our ship-based survey and another further south at a pier of the Virginia Institute of Marine Science (VIMS; $37.2473^{\circ}$ $\mathrm{N}, 76.4994^{\circ} \mathrm{W}$ ) near the bay mouth. A similar study was conducted during $18-24$ August 2014 (Supplementary Fig. 1). We also conducted a spring survey (11-16 April 2015) to get an initial condition before the hypoxia season (Fig. 1b)

Sample and analytical methods. Salinity, temperature, and $\mathrm{O}_{2}$ were obtained from the CTD Rosette system. Total sulfide $\left(\mathrm{H}_{2} \mathrm{~S}\right.$ and $\left.\mathrm{HS}^{-}\right)$was determined by voltammetry using solid state $\mathrm{Au} / \mathrm{Hg}$ electrodes ${ }^{36,39,43}$. Surface water partial pressure of $\mathrm{CO}_{2}\left(p \mathrm{CO}_{2}\right)$, position, temperature, and salinity information were measured underway while the ship was sailing or anchored by pumping surface water from under the ship to the shipboard laboratory using an underway $p \mathrm{CO}_{2}$ system $^{72}$. TA and DIC water samples were taken from Niskin bottles and were preserved and stored in $250 \mathrm{ml}$ borosilicate glass bottles with $100 \mu \mathrm{l}$ saturated $\mathrm{HgCl}_{2}$ solution ${ }^{73}$. TA and DIC samples were stored at refrigerated temperature ( $\sim 5$ ${ }^{\circ} \mathrm{C}$ ) before being measured (within 4 weeks). TA samples were measured by opencell Gran titration with a precision better than $\pm 0.1 \%$ using an Apollo Scitech Seawater Total Alkalinity titration system ${ }^{73}$. DIC samples were analyzed by adding phosphoric acid into sample waters to release $\mathrm{CO}_{2}$, which was measured by an infrared $\mathrm{CO}_{2}$ analyzer (LI-COR 7000) with an overall precision of $\pm 0.1 \%$ using an Apollo Scitech DIC Analyzer ${ }^{73}$. Both TA and DIC measurements were quality controlled by Certified Reference Materials from Andrew Dickson of the University of California at San Diego. pH samples were taken by the same Niskin bottle and were measured by an Orion Ross glass electrode within $1 \mathrm{~h}$ after the water temperature was stable in a $25.0 \pm 0.1^{\circ} \mathrm{C}$ thermal bath on the research vessel. The electrode was calibrated against three NBS (NIST) standards and $\mathrm{pH}$ values are reported in NBS scale and at $25^{\circ} \mathrm{C}$. Note that $\mathrm{pH}$ values in NBS scale are about 0.1 $\mathrm{pH}$ unit higher than those reported in total $\mathrm{H}^{+}$scale $\left(\mathrm{pH}_{\mathrm{T}}\right)$ elsewhere.

Uncertainty in determining DIC and TA enrichment. We averaged all subsurface and bottom waters $\left(S>11 \mathrm{~g} \mathrm{~kg}^{-1}\right)$ to derive a DIC enrichment of $275.3 \pm 59.5$ and a TA enrichment of $127.3 \pm 54.2 \mu \mathrm{mol} \mathrm{kg}^{-1}$ with respect to their expected conservative behaviors. The TA enrichment is underestimated because of a technical challenge caused by $\mathrm{HgS}$ precipitation, which releases $\mathrm{H}^{+}$when $\mathrm{HgCl}_{2}$ was used to stop microbial activity ${ }^{18}$, and/or oxidation of $\mathrm{H}_{2} \mathrm{~S}$ and $\mathrm{NH}_{4}{ }^{+}$during sample storage and/or analysis (which also generate $\mathrm{H}^{+}$). TA values calculated from DIC and $\mathrm{pH}$ analyzed onboard (neither is subject to the sample preservation and storage problems) agree well with measured TA except in the bottom waters (Supplementary Fig. 11a), and the disagreement increases as $\left[\mathrm{H}_{2} \mathrm{~S}\right]$ increases (Supplementary Fig. 11b). The internal consistency analysis suggests that TA reduction due to sample preservation and storage is $40 \pm 20 \mu \mathrm{mol} \mathrm{kg}^{-1}$; thus, the most likely TA enrichment in the bottom water is $(127.3 \pm 54.2)+(40 \pm 20)=167.3 \pm$ $57.6 \mu \mathrm{mol} \mathrm{kg}^{-1}$.

Determination of the endmembers and mixing lines. Lowest salinity values (from the station immediately downstream of the Susquehanna River) were selected as the river endmember values $(S$, TA, and DIC were measured as $0.189 \mathrm{~g}$ $\mathrm{kg}^{-1}, 1089.2 \mu \mathrm{mol} \mathrm{kg}-1$, and $1115.1 \mu \mathrm{mol} \mathrm{kg}-1$, respectively), though the station near the canal had the lowest TA and DIC due to mixing of water from the Delaware Bay. The offshore end-member data were collected at Latitude and Longitude of $37.13333^{\circ} \mathrm{N}$ and $73.32533^{\circ} \mathrm{W}$ on August 14 at the end of the cruise. We took the average values of the surface $45 \mathrm{~m}$ as the ocean endmember $(S=$ $33.618 \pm 0.139 \mathrm{~g} \mathrm{~kg}^{-1}, \mathrm{TA}=2248.4 \pm 78.4 \mu \mathrm{mol} \mathrm{kg}^{-1}$, and DIC $=2037.9 \pm 72.4$ $\left.\mu \mathrm{mol} \mathrm{kg}{ }^{-1}\right)$. So, the TA conservative mixing line is $\mathrm{TA}=34.676 \times \mathrm{S}+1082.7$ and the DIC line is DIC $=27.607 \times \mathrm{S}+1109.9$.

Calculation of air-sea $\mathrm{CO}_{2}$ flux and the DIC increase. Water surface $p \mathrm{CO}_{2}$ was measured every 1-1.5 min with calibrations every 6-12 h (August 2013, August 2014 , and April 2015). Atmospheric $p \mathrm{CO}_{2}$ values were also measured every $2-4 \mathrm{~h}$ during these cruises. Both atmosphere and water $\mathrm{CO}_{2}$ values were measured in a dry condition $\left(x \mathrm{CO}_{2}\right)$ and were converted to $p \mathrm{CO}_{2}$ in $100 \%$ water saturated conditions inside the equilibrator $\left(p \mathrm{CO}_{2(\mathrm{eq})}\right)$ by considering water vapor pressure:

$$
p \mathrm{CO}_{2(\mathrm{eq})}=x \mathrm{CO}_{2(\mathrm{eq})} \times\left(P_{\mathrm{b}}-P_{\text {weq }}\right)
$$

where $P_{\mathrm{b}}$ is barometric pressure and $P_{\text {weq }}$ is water vapor pressure in the equilibrator. For water data, the $p \mathrm{CO}_{2(\mathrm{eq})}$ is further converted to estuarine surface water $p \mathrm{CO}_{2}\left(p \mathrm{CO}_{2 \text { (water) }}\right)$ by considering temperature changes between the surface water and the equilibrator through the following equation ${ }^{72}$ :

$$
p \mathrm{CO}_{2(\text { water })}=p \mathrm{CO}_{2(\mathrm{eq})} \times \exp \left(0.043 \times\left(\mathrm{SST}-T_{\text {eq }}\right)\right)
$$

where SST is sea surface temperature $\left({ }^{\circ} \mathrm{C}\right)$ and $T_{\mathrm{eq}}$ is temperature in the equilibrator. Our measured atmospheric $x \mathrm{CO}_{2}$ values were also converted from dry condition to near sea surface wet condition $\left(p \mathrm{CO}_{2(\text { air })}\right)$ by Eq. (10):

$$
p \mathrm{CO}_{2(\text { air })}=x \mathrm{CO}_{2(\mathrm{eq})} \times\left(P_{\mathrm{b}}-P_{\mathrm{w}}\right)
$$

Here $P_{\mathrm{b}}$ is barometric pressure and $P_{\mathrm{w}}$ is water vapor pressure at the sea surface. Each $p \mathrm{CO}_{2 \text { (water) }}$ and its corresponding $p \mathrm{CO}_{2 \text { (air) }}$ were used to calculate the gas exchange flux $\left(F_{\mathrm{CO} 2}\right)$ between atmosphere and water by Eq. (11).

$$
F_{\mathrm{CO} 2}=C_{2} \times k \times K_{0} \times\left(p \mathrm{CO}_{2(\text { water })}-p \mathrm{CO}_{2(\text { air })}\right)
$$

where $k$ represents the gas transfer velocity and $K_{0}$ is the solubility of $\mathrm{CO}_{2}{ }^{74}$. We adopted Ho et al..$^{75}$ as the gas transfer velocity and an ensemble of gas transfer parameters to evaluate the uncertainty range following the previous practice ${ }^{72,}, 76$ Finally, the coefficient $\mathrm{C}_{2}$ corrects the non-symmetrical distribution of wind ${ }^{76}$. A negative air-sea $\mathrm{CO}_{2}$ flux means an uptake of atmospheric $\mathrm{CO}_{2}$ for the water.

Over at least a 100-day water residence period (from May to August) and over a water column of $20 \mathrm{~m}$, this $\mathrm{CO}_{2}$ flux can be converted into an increase in DIC of, $4.3-6.7\left(\mathrm{mmol} \mathrm{m}^{-2} \mathrm{~d}^{-1}\right) \times 100 \mathrm{~d} / 20 \mathrm{~m} \approx 21.5-33.5 \mathrm{mmol} \mathrm{m}^{-3}$ or $21.2-$

$33.1 \mu \mathrm{mol} \mathrm{kg}^{-1}$ (here a density of $1012.09 \mathrm{~kg} \mathrm{~m}^{-3}$ is used). We used the entire water column rather than the surface mixed layer because the main concern here is how local $\mathrm{CO}_{2}$ uptake, via internal mixing, contributes to acidification of the especially vulnerable bottom waters.

Calculation of $\mathbf{p H}$ decrease due to local $\mathrm{CO}_{2}$ uptake. With $\mathrm{H}_{2} \mathrm{~S}$ included, the calculation of $\mathrm{pH}$ (in NBS scale and at $25^{\circ} \mathrm{C}$ ) decrease was performed using the modified CO2SYS program. Note another program, AquaEnv, also has such a capacity ${ }^{77}$. We used day 4 data with $S=18.618 \mathrm{~g} \mathrm{~kg}^{-1}, T=25.28^{\circ} \mathrm{C}$, depth $=17 \mathrm{~m}$, DIC $=1933.8 \mu \mathrm{mol} \mathrm{kg}{ }^{-1}$, total $\left[\mathrm{H}_{2} \mathrm{~S}\right]=37.79 \mu \mathrm{mol} \mathrm{kg}{ }^{-1},\left[\mathrm{NH}_{3}+\mathrm{NH}_{4}{ }^{+}\right]=13.6 \mu \mathrm{mol}$ $\mathrm{kg}^{-1}, \mathrm{~T}-\mathrm{PO}_{4}=3.5 \mu \mathrm{mol} \mathrm{kg}{ }^{-1}$, and $\mathrm{pH}=7.476$ to calculate a TA $=1934.1 \mu \mathrm{mol} \mathrm{kg}-1$ Then, we subtracted the summer DIC by $21.2-33.1 \mu \mathrm{mol} \mathrm{kg}{ }^{-1}(=1912.6-1900.7$ $\left.\mu \mathrm{mol} \mathrm{kg}^{-1}\right)$ to calculate a new $\mathrm{pH}(7.557-7.604)$. Thus, the $\mathrm{pH}$ decrease by an increase of DIC derived from local uptake of atmospheric $\mathrm{CO}_{2}$ is $0.081-0.128 \mathrm{pH}$ unit over the entire period from spring to summer.

pH decrease due to oxidation of reduced chemicals. We used day 4 data with $S=15.145 \mathrm{~g} \mathrm{~kg}^{-1}, T=25.36^{\circ} \mathrm{C}$, depth $=12.54 \mathrm{~m}, \mathrm{DIC}=1767.7 \mu \mathrm{mol} \mathrm{kg}{ }^{-1},\left[\mathrm{H}_{2} \mathrm{~S}\right]=$ $2 \mu \mathrm{mol} \mathrm{kg}$, and $\mathrm{pH}=7.354$ to calculate a TA $=1698.8 \mu \mathrm{mol} \mathrm{kg}^{-1}$. Then, we subtracted a $30-60 \mu \mathrm{mol} \mathrm{\textrm {kg } ^ { - 1 }}$ from TA to calculate a new $\mathrm{pH}(7.152-7.246)$. Thus, the $\mathrm{pH}$ decrease by a $30-60 \mu \mathrm{mol} \mathrm{kg}^{-1}$ of TA reduction is $0.108-0.202 \mathrm{pH}$ units (represented by the purple arrows in Fig. 4b). The modified version of CO2SYS was used for all the $\mathrm{CO}_{2}$ and $\mathrm{pH}$ calculations. Note, adding a $<3 \mu \mathrm{mol} \mathrm{kg}{ }^{-1}$ of T-PO would only lead to $<0.005 \mathrm{pH}$ unit decrease in the calculation. Thus, its infleunce is ignored here.

Modification of the CO2SYS program. The modifications were done on the Excel version 2.1 of the program ${ }^{78}$, which is available for download from CDIAC (http:// cdiac.ornl.gov/ftp/co2sys/). A Matlab version is available from the corresponding author. In addition to the total Phosphate and Silicate, the program now accepts the total $\mathrm{NH}_{3}$ and total $\mathrm{H}_{2} \mathrm{~S}$ in $\mu \mathrm{mol}(\mathrm{kg} \text { of SW })^{-1}$. The contribution of each to the alkalinity is given by:

$$
\mathrm{NH}_{3}-\mathrm{Alk}=\left[\mathrm{NH}_{3}\right]_{\mathrm{T}} \frac{K_{\mathrm{NH}_{3}}}{K_{\mathrm{NH}_{3}}+[\mathrm{H}]}
$$

and

$$
\mathrm{H}_{2} \mathrm{~S}-\text { Alk }=\left[\mathrm{H}_{2} \mathrm{~S}\right]_{\mathrm{T}} \frac{K_{\mathrm{H} 2 \mathrm{~S}}}{K_{\mathrm{H} 2 \mathrm{~S}}+[\mathrm{H}]}
$$

where $K_{\mathrm{NH}_{3}}$ and $K_{\mathrm{H} 2 \mathrm{~S}}$ are the dissociation constants of ammonium $\left(\mathrm{NH}_{4}^{+}\right)$and hydrogen sulfide $\left(\mathrm{H}_{2} \mathrm{~S}\right)$.

The dissociation constant for $\mathrm{NH}_{4}{ }^{+}$was taken from Clegg and Whitfield ${ }^{79}$ and is valid for $S=0-40 \mathrm{~g} \mathrm{~kg}^{-1}$ and $t=-2$ to $40{ }^{\circ} \mathrm{C}$ (note ref. ${ }^{21}$ essentailly provided the same constant). The constant for $\mathrm{H}_{2} \mathrm{~S}$ was taken from Millero et al. ${ }^{80}$ and is valid for $S=0-40 \mathrm{~g} \mathrm{~kg}^{-1}$ and $t=0-35^{\circ} \mathrm{C}$. When the pressure is not zero, a correction is applied according to Millero ${ }^{81}$. A comparison with AquaEnv under $\left[\mathrm{H}_{2} \mathrm{~S}\right]<50$ (or

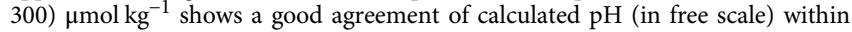
0.0003 (or 0.0026) from known TA and DIC. We have further tested the calculations with waters containing high concentrations of $\mathrm{H}_{2} \mathrm{~S}$ and posted this modified version of the CO2SYS program on the CDIAC website for public access $^{82}$.

Simulation of bottom-water geochemical pathways. We present here the calculation methods for Table 2 and Fig. 4a, b. For the bottom-water condition $(S=$ $19.87 \mathrm{~g} \mathrm{~kg}^{-1}$ and $T=25^{\circ} \mathrm{C}$ ), we have a saturated $\left[\mathrm{O}_{2}\right]=231.7 \mu \mathrm{mol} \mathrm{kg}^{-1}$, and, from the mixing line at $S=19.87 \mathrm{~g} \mathrm{~kg}^{-1}, \mathrm{TA}=1771.1 \mu \mathrm{mol} \mathrm{kg}{ }^{-1}$ and DIC $=1658.5 \mu \mathrm{mol}$ $\mathrm{kg}^{-1}$, we have $\mathrm{pH}=8.066$. If all dissolved $\mathrm{O}_{2}$ is used by heterotrophic bacteria for organic carbon respiration via Redfield stoichiometry 45,83 , it would increase DIC by $178.0 \mu \mathrm{mol} \mathrm{kg}^{-1}$ and decrease TA by $28.5 \mu \mathrm{mol} \mathrm{kg}^{-1}$. To be consistent with our observation, $\mathrm{SR}$ and $\mathrm{CaCO}_{3}$ dissolution must have increased bottom-water TA by a 
total of $195.9 \mu \mathrm{mol} \mathrm{kg}^{-1}$ (i.e., observed $167.3 \mu \mathrm{mol} \mathrm{kg}{ }^{-1}$ plus expected $-28.5 \mu \mathrm{mol}$ $\mathrm{kg}^{-1}$ ) beyond conservative mixing. We estimate TA increase from $\mathrm{SO}_{4}{ }^{2-}$ reduction as $80.6 \mu \mathrm{mol} \mathrm{kg}^{-1}$ from the total concentration of $\mathrm{H}_{2} \mathrm{~S}\left(35 \mu \mathrm{mol} \mathrm{kg}^{-1}\right)^{39}$ by the following equation:

$$
\Delta \mathrm{TA}=\left(2 \times\left[\mathrm{H}_{2} \mathrm{~S}\right]+16 / 53 \times\left[\mathrm{H}_{2} \mathrm{~S}\right]\right)
$$

where $2 \times\left[\mathrm{H}_{2} \mathrm{~S}\right]$ represents an equal amount of $\mathrm{HCO}_{3}{ }^{-}$and $\mathrm{HS}^{-}$production during $\mathrm{SO}_{4}{ }^{2-}$ reduction and $16 / 53 \times\left[\mathrm{H}_{2} \mathrm{~S}\right]$ represents $\mathrm{NH}_{3}$ production (and contribution to TA) based on stoichiometry (see Table 2). Then the TA generated from $\mathrm{CaCO}_{3}$ dissolution must be as high as $115.3 \pm 20.0 \mu \mathrm{mol} \mathrm{kg}^{-1}$ by the difference (195.9-80.6) and contributes up to $70 \%$ of total amount of TA production. The amount of DIC production following these steps is $305.6 \pm 10.0 \mu \mathrm{mol} \mathrm{kg}^{-1}$. This is within the uncertainty of the observed value of $275.3 \pm 59.5$ (Fig. 3). The $10 \%$ difference $(30 \mu \mathrm{mol} \mathrm{kg}-1)$ can be explained either by TA increase due to organic matter respiration using nitrate (denitrification) and metal oxides ${ }^{13}, 45$ and/or the deviation of $\mathrm{C} / \mathrm{N}$ ratio from the Redfield ratio ${ }^{13}, 84,85$ as well as probably organic alkalinity contribution ${ }^{86}$. Indeed if a lower $\mathrm{C}$ to $-\mathrm{O}_{2}$ ratio $(106 / 154=0.688)$ given in ref. ${ }^{84}$ is used, the produced DIC would be close to the observation.

From the resulting $\mathrm{pH}$ and $\Omega_{\text {arag }}$ (Table 2), it is clear when $\mathrm{O}_{2}$ is partially consumed aragonite mineral becomes undersaturated (starting at $75 \% \mathrm{O}_{2}$ saturation) and $\mathrm{CaCO}_{3}$ dissolution can proceed together with AR. To simulate the observed DIC (measured) and TA (calculated from DIC and $\mathrm{pH}$ ) data, we assume the dissolution does not occur until a sufficiently low $\Omega_{\text {arag }}$ in waters and that the first $20 \%$ of $\mathrm{CaCO}_{3}$ dissolution occurs before or at $\mathrm{DO}=33 \%$. Then the second, third and fourth $20 \%$ of the $\mathrm{CaCO}_{3}$ dissolution occurs before or at $\mathrm{DO}=16 \%, 8 \%$, and $0 \%$, respectively. The last $20 \%$ of the $\mathrm{CaCO}_{3}$ dissolution occurs together with SR.

Simulation of pH changes. We present here the calculation methods for Fig. $5 \mathrm{a}, \mathrm{b}$. Although each term in Eq. (5) may be derived analytically, in this paper, we obtain the overall $\mathrm{pH}$ change, $\Delta \mathrm{pH}$ (presented in Fig. $5 \mathrm{c}$ ), numerically using the updated CO2SYS program. Conditions used are given below.

We assume a present day atmospheric dry $\mathrm{CO}_{2}$ fraction $\left(x \mathrm{CO}_{2}\right)$ as of $396.2 \mathrm{ppm}$ and the corresponding water $p \mathrm{CO}_{2}=384.0 \mu \mathrm{atm}$ at $25^{\circ} \mathrm{C}$ and salinity $=36.0 \mathrm{~g} \mathrm{~kg}^{-1}$. $x \mathrm{CO}_{2}$ is set to $281.3 \mathrm{ppm}$ for the pre-industrial era and $798.0 \mathrm{ppm}$ for year 2100 .

For the Chesapeake Bay simulation, we take TA from the offshore water at 74.9 $\mathrm{m}, S=35.839 \mathrm{~g} \mathrm{~kg}^{-1}$, and TA $=2351.5 \mu \mathrm{mol} \mathrm{kg} \mathrm{kg}^{-1}$. Equilibrium of this water with the atmosphere yield a DIC $=2030.3 \mu \mathrm{mol} \mathrm{kg}^{-1}$ and $\mathrm{pH}=8.198$ (in NBS scale) at $25^{\circ} \mathrm{C}$ and $1 \mathrm{~m}$ of water depth. For the Gulf of Mexico water, we take the endmember values from Cai et al. ${ }^{9}$ and adjust the present condition slightly to the

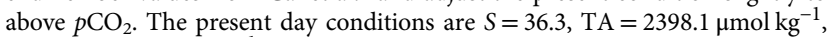
DIC $=2065.2 \mu \mathrm{mol} \mathrm{kg}-1, \mathrm{pH}=8.203$ at $25^{\circ} \mathrm{C}$ and $1 \mathrm{~m}$ water depth.

For the Mississippi River end-member conditions, we have $S=0.1 \mathrm{~g} \mathrm{~kg}^{-1}$, $\mathrm{TA}=2400 \mu \mathrm{mol} \mathrm{kg}-1$, DIC $=2430 \mu \mathrm{mol} \mathrm{kg}-1$, and $p \mathrm{CO}_{2}=1388.9 \mu \mathrm{atm}$. For the Susquehanna River, we have $S=0.189 \mathrm{~g} \mathrm{~kg}^{-1}, \mathrm{TA}=1089.2 \mu \mathrm{mol} \mathrm{kg}-1, \mathrm{DIC}=1135$ $\mu \mathrm{mol} \mathrm{kg}{ }^{-1}$, and $p \mathrm{CO}_{2}=1514.9 \mu \mathrm{atm}$.

For Mississippi/GOM bottom water, at $S=34 \mathrm{~g} \mathrm{~kg}^{-1}, T=25^{\circ} \mathrm{C}$, and $\left[\mathrm{O}_{2}\right]=$ $216.0 \mu \mathrm{mol} \mathrm{kg}{ }^{-1}$, complete $\mathrm{O}_{2}$ consumption would lead to a DIC increase of $216 \times$ $106 / 138=165.9 \mu \mathrm{mol} \mathrm{kg}{ }^{-1}$ and a TA decrease of $26.6 \mu \mathrm{mol} \mathrm{kg}{ }^{-1}$. For Chesapeake Bay bottom water, at $S=20 \mathrm{~g} \mathrm{~kg}^{-1}, T=25^{\circ} \mathrm{C}$, and $\left[\mathrm{O}_{2}\right]=232.6 \mu \mathrm{mol} \mathrm{kg}{ }^{-1}$, complete $\mathrm{O}_{2}$ consumption would lead to a DIC increase of $216 \times 106 / 138=178.7$ $\mu \mathrm{mol} \mathrm{kg}-1$ and a TA decrease of $28.7 \mu \mathrm{mol} \mathrm{kg} \mathrm{kg}^{-1}$.

Buffer factor calculation. We calculate these buffer factors (Fig. 5) following the analytical formula provided by Egleston et al. ${ }^{54}$ with a typo corrected ${ }^{87}$. Specifically, we extract out species concentrations and thermodynamic constants from the updated version of CO2SYS. We also compare results with those calculated with two other programs AquaEnv and SEACARB (http://CRAN.R-project.org/ package $=$ seacarb) and the agreement is reasonable (within $8 \mu \mathrm{mol} \mathrm{kg}^{-1}$ or $3 \%$ ) as is expected. Although $\mathrm{H}_{2} \mathrm{~S}$ and $\mathrm{NH}_{4}$ are not included in the analytical equations, as our equilibrium calculation already include these acid-base species and $\left[\mathrm{H}_{2} \mathrm{~S}\right]$ and $\left[\mathrm{NH}_{4}\right]$ are not high in the bay, the calculated results are similar to those from the AquaEnv which includes fully these reduced chemical species. Finally, in Fig. 3b, for the real system buffer factors, we directly use AquaEnv. Given the low $\left[\mathrm{H}_{2} \mathrm{~S}\right]$ in the bay, with or without $\mathrm{H}_{2} \mathrm{~S}$ have only resulted in a minor difference in buffer factor calculation.

Computer program availability. The modified CO2SYS program on Excel version 2.1 is available for download from CDIAC (http://cdiac.ornl.gov/ftp/co2sys/). The Matlab version is available from the corresponding author upon reasonable request.

Data availability. All data are available from the corresponding author upon reasonable request and will be deposited at the US National Centers for Environmental Information (https://www.nodc.noaa.gov/oceanacidification/).
Received: 19 February 2017 Accepted: 27 June 2017

Published online: 28 August 2017

\section{References}

1. IPCC. Climate Change 2013. The Physical Science Basis. Contribution of Working Group I to the Fifth Assessment Report of the Intergovernmental Panel on Climate Change (2014).

2. Sabine, C. L. et al. The oceanic sink for anthropogenic $\mathrm{CO}_{2}$. Science 305, 367-371 (2004).

3. Orr, J. C. et al. Anthropogenic ocean acidification over the twenty-first century and its impact on calcifying organisms. Nature 437, 681-686 (2005).

4. Caldeira, K. \& Wickett, M. E. Anthropogenic carbon and ocean pH. Nature 425, 365-365 (2003)

5. Doney, S. C. The growing human footprint on coastal and open-ocean biogeochemistry. Science 328, 1512-1516 (2010).

6. Hoegh-Guldberg, O. \& Bruno, J. F. The impact of climate change on the world's marine ecosystems. Science 328, 1523-1528 (2010).

7. Riebesell, U. \& Gattuso, J.-P. Lessons learned from ocean acidification research. Nat. Clim. Change 5, 12-14 (2015).

8. Feely, R. A. et al. The combined effects of ocean acidification, mixing, and respiration on $\mathrm{pH}$ and carbonate saturation in an urbanized estuary. Estuar., Coast. Shelf Sci. 88, 442-449 (2010).

9. Cai, W.-J. et al. Acidification of subsurface coastal waters enhanced by eutrophication. Nat. Geosci. 4, 766-770 (2011).

10. Wallace, R. B., Baumann, H., Grear, J. S., Aller, R. C. \& Gobler, C. J. Coastal ocean acidification: the other eutrophication problem. Estuar., Coast. Shelf Sci. 148, 1-13 (2014)

11. Sunda, W. G. \& Cai, W.-J. Eutrophication induced $\mathrm{CO}_{2}$-acidification of subsurface coastal waters: interactive effects of temperature, salinity, and atmospheric $\mathrm{P}_{\mathrm{CO} 2}$. Environ. Sci. Technol. 46, 10651-10659 (2012).

12. Hagens, M. et al. Biogeochemical processes and buffering capacity concurrently affect acidification in a seasonally hypoxic coastal marine basin. Biogeosciences 12, 1561-1583 (2015).

13. Ulfsbo, A., Hulth, S. \& Anderson, L. G. pH and biogeochemical processes in the Gotland Basin of the Baltic Sea. Mar. Chem. 127, 20-30 (2011).

14. Galloway, J. N. et al. Transformation of the nitrogen cycle: recent trends, questions, and potential solutions. Science 320, 889-892 (2008).

15. Diaz, R. J. \& Rosenberg, R. Spreading dead zones and consequences for marine ecosystems. Science 321, 926-929 (2008).

16. Rabalais, N. N. et al. Eutrophication-driven deoxygenation the coastal ocean. Oceanography 27, 172-183 (2014).

17. Edman, M. \& Omstedt, A. Modeling the dissolved $\mathrm{CO}_{2}$ system in the redox environment of the Baltic Sea. Limnol. Oceanogr. 58, 74-92 (2013).

18. Hiscock, W. T. \& Millero, F. J. Alkalinity of the anoxic waters in the Western Black Sea. Deep Sea Res. Part II: Top. Stud. Oceanogr. 53, 1787-1801 (2006).

19. Konovalov, S. K., Murray, J. W., Luther, G. W. \& Tebo, B. M. Processes controlling the redox budget for the oxic/anoxic water column of the Black Sea. Deep Sea Res. Part II: Top. Stud. Oceanogr. 53, 1817-1841 (2006).

20. Pakhomova, S., Braaten, H. F. V., Yakushev, E. \& Skei, J. Biogeochemical consequences of an oxygenated intrusion into an anoxic fjord. Geochem. Trans. 15, 1-12 (2014).

21. Yao, W. \& Millero, F. J. The chemistry of the anoxic waters in the Framvaren Fjord, Norway. Aquat. Geochem. 1, 53-88 (1995).

22. Zhang, J.-Z. \& Millero, F. J. The chemistry of the anoxic waters in the Cariaco Trench. Deep Sea Res. Part I: Oceanogr. Res. Pap. 40, 1023-1041 (1993).

23. Kemp, W. M. et al. Eutrophication of Chesapeake Bay: historical trends and ecological interactions. Mar. Ecol.-Prog. Ser. 303, 1-29 (2005).

24. Boynton, W. R., Garber, J. H., Summers, R. \& Kemp, W. M. Inputs, transformations, and transport of nitrogen and phosphorus in Chesapeake Bay and selected tributaries. Estuaries 18, 285-314 (1995).

25. Kemp, W. M., Smith, E. M., Marvin-DiPasquale, M. \& Boynton, W. R. Organic carbon balance and net ecosystem metabolism in Chesapeake Bay. Mar. Ecol. Prog. Ser. 150, 229-248 (1997).

26. Waldbusser, G., Voigt, E., Bergschneider, H., Green, M. \& Newell, R. E. Biocalcification in the Eastern Oyster (Crassostrea virginica) in relation to longterm trends in Chesapeake Bay pH. Estuar. Coasts 34, 221-231 (2011).

27. Raymond, P. A., Bauer, J. E. \& Cole, J. J. Atmospheric $\mathrm{CO}_{2}$ evasion, dissolved inorganic carbon production, and net heterotrophy in the York River Estuary. Limnol. Oceanogr. 45, 1707-1717 (2000).

28. Wong, G. T. F. Alkalinity and $\mathrm{pH}$ in the Southern Chesapeake Bay and and the James River Estuary. Limnol. Oceanogr. 24, 970-977 (1979).

29. Li, M., Zhong, L., Boicourt, W. C., Zhang, S. \& Zhang, D.-L. Hurricane-induced destratification and restratification in a partially-mixed estuary. J. Mar. Res. 65, 169-192 (2007).

30. Goodrich, D. M., Boicourt, W. C., Hamilton, P. \& Pritchard, D. W. Windinduced destratification in Chesapeake Bay. J. Phys. Oceanogr. 17, 2232-2240 (1987). 
31. Li, M. \& Zhong, L. Flood-ebb and spring-neap variations of mixing, stratification and circulation in Chesapeake Bay. Cont. Shelf Res. 29, 4-14 (2009).

32. Smith, E. M. \& Kemp, W. M. Seasonal and regional variations in plankton community production and respiration for Chesapeake Ba. Mar. Ecol. Prog. Ser. 116, 217-231 (1995).

33. Marvin-DiPasquale, M. C. \& Capone, D. G. Benthic sulfate reduction along the Chesapeake Bay central channel. I. Spatial trends and controls. Mar. Ecol. Prog. Ser. 168, 213-228 (1998).

34. Roden, E. E. \& Tuttle, J. H. Sulfide release from estuarine sediments underlying anoxic bottom water. Limnol. Oceanogr. 37, 725-738 (1992).

35. Duarte, C. et al. Is ocean acidification an open-ocean syndrome? Understanding anthropogenic impacts on seawater pH. Estuar. Coasts 36, 221-236 (2013).

36. Luther, G. W. et al. The roles of anoxia, $\mathrm{H}_{2} \mathrm{~S}$, and storm events in fish kills of dead-end canals of Delaware Inland Bays. Estuaries 27, 551-560 (2004).

37. Dai, M. et al. Diurnal variations of surface seawater $\mathrm{CO}_{2}$ in contrasting coastal environments. Limnol. Oceanogr. 54, 735-745 (2009).

38. Breitburg, D. L. et al. And on top of all that... coping with ocean acidification in the midst of many stressors. Oceanography 28, 48-61 (2015).

39. Oldham, V. E., Owings, S. M., Jones, M. R., Tebo, B. M. \& Luther, G. W. III Evidence for the presence of strong $\mathrm{Mn}$ (III)-binding ligands in the water column of the Chesapeake Bay. Mar. Chem. 171, 58-66 (2015).

40. Findlay, A. J. et al. Distribution and size fractionation of elemental sulfur in aqueous environments: the Chesapeake Bay and Mid-Atlantic Ridge. Geochim. Cosmochim. Acta 142, 334-348 (2014).

41. Lee, D. Y., Owens, M. S., Crump, B. C. \& Cornwell, J. C. Elevated microbial $\mathrm{CO}_{2}$ production and fixation in the oxic/anoxic interface of estuarine water columns during seasonal anoxia. Estuar., Coast. Shelf Sci. 164, 65-76 (2015).

42. Cai, W. J. \& Reimers, C. E. The development of $\mathrm{pH}$ and $\mathrm{pCO}_{2}$ microelectrodes for studying the carbonate chemistry of pore waters near the sediment-water interface. Limnol. Oceanogr. 38, 1762-1773 (1993).

43. Luther, G. W., Reimers, C., Nuzzio, D. B. \& Lovalvo, D. In situ deployment of voltammetric, potentiometric, and amperometric microelectrodes from a ROV to determine dissolved $\mathrm{O}_{2}, \mathrm{Mn}, \mathrm{Fe}, \mathrm{S}(-2)$, and $\mathrm{pH}$ in porewaters. Environ. Sci. Technol. 33, 4352-4356 (1999).

44. Boudreau, B. P. A method-of-line code for carbon and nutrient daigenesis in aquatic sediments. Comput. Geosci. 22, 479-496 (1996).

45. Wang, Y. \& Van Cappellen, P. A multicomponent reaction transport model of early diagenesis: application to redox cycling in coastal marine sediments. Geochim. Cosmochim. Acta 60, 2993-3014 (1996).

46. Emerson, S., Cranston, R. E. \& Liss, P. S. Redox species in a reducing fjord: equilibrium and kinetic considerations. Deep Sea Res. 26A, 859-878 (1979).

47. Cai, W. J. et al. The biogeochemistry of inorganic carbon and nutrients in the Pearl River estuary and the adjacent Northern South China Sea. Cont. Shelf Res. 24, 1301-1319 (2004)

48. Waldbusser, G. G., Powell, E. N. \& Mann, R. Ecosystem effects of shell aggregations and cycling in coastal waters: an example of Chesapeake Bay oyster reefs. Ecology 94, 895-903 (2013).

49. Abril, G., Etcheber, H., Delille, B., Frankignoulle, M. \& Borges, A. V. Carbonate dissolution in the turbid and eutrophic Loire estuary. Mar. Ecol.-Prog. Ser. 259, 129-138 (2003)

50. Middelburg, J. J., Soetaert, K., Herman, P. M. J. \& Heip, C. H. R. Denitrification in marine sediments: a model study. Glob. Biogeochem. Cycles 10, 661-673 (1996).

51. $\mathrm{Hu}, \mathrm{X}$. \& Cai, W.-J. The impact of denitrification on the atmospheric $\mathrm{CO}_{2}$ uptake potential of seawater. Mar. Chem. 127, 192-198 (2011).

52. Kana, T. M., Cornwell, J. C. \& Zhong, L. Determination of denitrification in the Chesapeake Bay from measurements of $\mathrm{N}_{2}$ accumulation in bottom water. Estuar. Coasts 29, 222-231 (2006).

53. Frankignoulle, M. A complete set of buffer factors for acid-base $\mathrm{CO}_{2}$ system in seawater. J. Mar. Syst. 5, 111-118 (1994).

54. Egleston, E. S., Sabine, C. L. \& Morel, F. M. M. Revelle revisited: buffer factors that quantify the response of ocean chemistry to changes in DIC and alkalinity. Glob. Biogeochem. Cycles 24, GB1002 (2010)

55. Hofmann, A. F., Middelburg, J. J., Soetaert, K., Wolf-Gladrow, D. A. \& Meysman, F. J. R. Proton cycling, buffering, and reaction stoichiometry in natural waters. Mar. Chem. 121, 246-255 (2010).

56. Hofmann, A. F., Middelburg, J. J., Soetaert, K. \& Meysman, F. J. R. pH modelling in aquatic systems with time-variable acid-base dissociation constants applied to the turbid, tidal Scheldt estuary. Biogeosciences $\mathbf{6}$, 1539-1561 (2009)

57. Hagens, M. \& Middelburg, J. J. Generalised expressions for the response of $\mathrm{pH}$ to changes in ocean chemistry. Geochim. Cosmochim. Acta 187, 334-349 (2016).

58. Hagens, M., Hunter, K. A., Liss, P. S. \& Middelburg, J. J. Biogeochemical context impacts seawater $\mathrm{pH}$ changes resulting from atmospheric sulfur and nitrogen deposition. Geophys. Res. Lett. 41, 935-941 (2014).

59. Wang, Z. A. et al. The marine inorganic carbon system along the Gulf of Mexico and Atlantic coasts of the United States: insights from a transregional coastal carbon study. Limnol. Oceanogr. 58, 325-342 (2013).
60. Hu, X. \& Cai, W.-J. Estuarine acidification and minimum buffer zone-a conceptual study. Geophys. Res. Lett. 40, 5176-5181 (2013).

61. Cai, W.-J. et al. A comparative overview of weathering intensity and $\mathrm{HCO}_{3}{ }^{-}$ flux in the world's major rivers with emphasis on the Changjiang, Huanghe, Zhujiang (Pearl) and Mississippi Rivers. Cont. Shelf Res. 28, 1538-1549 (2008)

62. Guo, X. et al. Carbon dynamics and community production in the Mississippi River plume. Limnol. Oceanogr. 57, 1-17 (2012).

63. Guo, X. et al. Seasonal variations in the inorganic carbon system in the Pearl River (Zhujiang) estuary. Cont. Shelf Res. 28, 1424-1434 (2008).

64. Mook, W. G. \& Koene, B. K. S. Chemistry of dissolved inorganic carbon in estuarine and coastal brackish waters. Estuar. Coast. Mar. Sci. 3, 325-336 (1975).

65. Whitfield, M. \& Turner, D. R. The carbon dioxide system in estuaries-An inorganic perspective. Sci. Total Environ. 49, 235-255 (1986).

66. Morel, F. M. M. \& Hering, J. G. Principles and Applications of Aquatic Chemistry 2nd edn, (John Wiley and Sons, 1992).

67. Luther, G. W. et al. Thermodynamics and kinetics of sulfide oxidation by oxygen: a Look at inorganically controlled reactions and biologically mediated processes in the environment. Front. Microbiol. 2, Article 62 (2011).

68. Geyer, W. R. \& MacCready, P. The estuarine circulation. Annu. Rev. Fluid Mech. 46, 175-197 (2014).

69. Kemp, W. \& Testa, J. Metabolic balance between ecosystem production and consumption. Treatise Estuar. Coast. Sci. 7, 83-118 (2011).

70. Bauer, J. E. et al. The changing carbon cycle of the coastal ocean. Nature 504 61-70 (2013).

71. Borges, A. V. \& Gypens, N. Carbonate chemistry in the coastal zone responds more strongly to eutrophication than ocean acidification. Limnol. Oceanogr. 55, 346-353 (2010).

72. Huang, W.-J., Cai, W.-J., Wang, Y., Lohrenz, S. E. \& Murrell, M. C. The carbon dioxide system on the Mississippi River-dominated continental shelf in the northern Gulf of Mexico: 1. Distribution and air-sea $\mathrm{CO}_{2}$ flux. J. Geophys. Res. Oceans 120, 1429-1445 (2015).

73. Huang, W.-J., Wang, Y. \& Cai, W.-J. Assessment of sample storage techniques for total alkalinity and dissolved inorganic carbon in seawater. Limnol. Oceanogr. Methods 10, 711-717 (2012).

74. Weiss, R. F. Carbon dioxide in water and seawater: the solution of a non-ideal gas. Mar. Chem. 2, 203-215 (1974).

75. Ho, D. T. et al. Measurements of air-sea gas exchange at high wind speeds in the Southern Ocean: implications for global parameterizations. Geophys. Res. Lett. 33, L16611 (2006).

76. Wanninkhof, R. Relationship between wind speed and gas exchange over the ocean revisited. Limnol. Oceanogr.: Methods 12, 351-362 (2014).

77. Hofmann, A., Soetaert, K., Middelburg, J. \& Meysman, F. R. AquaEnv: an aquatic acid-base modelling environment in R. Aquat. Geochem. 16, 507-546 (2010).

78. Pierrot, D., Lewis, E. \& Wallace, D. W. R. MS Excel Program Developed for $\mathrm{CO}_{2}$ System Calculations (Oak Ridge National Laboratory, 2006).

79. Clegg, S. L. \& Whitfield, M. A chemical model of seawater including dissolved ammonia and the stoichiometric dissociation constant of ammonia in estuarine water and seawater from -2 to $40{ }^{\circ} \mathrm{C}$. Geochim. Cosmochim. Acta 59 , 2403-2421 (1995).

80. Millero, F. J., Plese, T. \& Fernandez, M. The dissociation of hydrogen sulfide in seawater. Limnol. Oceanogr. 33, 269-274 (1988).

81. Millero, F. J. Thermodynamics of the carbon-dioxide system in the oceans. Geochim. Cosmochim. Acta 59, 661-677 (1995).

82. Xu, Y.-Y., Cai, W.-J., Pierrot, D. Ocean carbonate system computation for anoxic waters using an updated CO2SYS program. Mar. Chem. https:/doi.org/ 10.1016/j.marchem.2017.07.002 (2017).

83. Cai, W.-J., Luther, G. III, Cornwell, J. \& Giblin, A. Carbon cycling and the coupling between proton and electron transfer reactions in aquatic sediments in Lake Champlain. Aquat. Geochem. 16, 421-446 (2010).

84. Hedges, J. I. et al. The biochemical and elemental compositions of marine plankton: a NMR perspective. Mar. Chem. 78, 47-63 (2002).

85. Chen, C.-T. A., Lin, C.-M., Huang, B.-T. \& Chang, L.-F. Stoichiometry of carbon, hydrogen, nitrogen, sulfur and oxygen in the particulate matter of the western North Pacific marginal seas. Mar. Chem. 54, 179-190 (1996).

86. Cai, W.-J., Wang, Y. \& Hodson, R. E. Acid-base properties of dissolved organic matter in the estuarine waters of Georgia. Geochim. Cosmochim. Acta 62 , 473-483 (1998).

87. Álvarez, M. et al. The $\mathrm{CO}_{2}$ system in the Mediterranean Sea: a basin wide perspective. Ocean Sci. 10, 69-92 (2014).

\section{Acknowledgements}

This work was supported by internal funds from the University of Delaware Provost's office and the College of Earth, Ocean and Environment Dean's office to W.-J.C., by grants from the National Science Foundation (NSF OCE-1559312) and NASA (NNX14AM37G) to W.-J.C., by grants from NSF (OCE-1155385) and the U.S. National Oceanic and Atmospheric Administration (NOAA) Sea Grant program

(NA14OAR4170087) to G.W.L., and a NOAA grant to J.T., W.-J.C., M.L., G.G.W., J.C., 
and W.M.K. (NA15NOS4780190, publication \# 17-001). We thank Xinping Hu for discussion and the Chesapeake Bay Program and the Maryland Department of Natural Resources for the monitoring data. This is UMCES publication number 5369.

\section{Author contributions}

W.-J.C. and G.W.L. are responsible for the design of the fieldwork. W.-J.C. is responsible for data analysis and writing of the paper. W.-J.H., M.X., A.J., R.M., J.B., N.H. are responsible for data collection and sample analysis. Y.-Y.X. contributes to buffer factor calculation. M.L. contributes to physical mixing part. J.T. and W.M.K. contribute to the biological production part. All authors have contributed to discussion and revision of the paper.

\section{Additional information}

Supplementary Information accompanies this paper at doi:10.1038/s41467-017-00417-7.

Competing interests: The authors declare no competing financial interests.

Reprints and permission information is available online at http://npg.nature.com/ reprintsandpermissions/
Publisher's note: Springer Nature remains neutral with regard to jurisdictional claims in published maps and institutional affiliations.

(c) (i) Open Access This article is licensed under a Creative Commons Attribution 4.0 International License, which permits use, sharing, adaptation, distribution and reproduction in any medium or format, as long as you give appropriate credit to the original author(s) and the source, provide a link to the Creative Commons license, and indicate if changes were made. The images or other third party material in this article are included in the article's Creative Commons license, unless indicated otherwise in a credit line to the material. If material is not included in the article's Creative Commons license and your intended use is not permitted by statutory regulation or exceeds the permitted use, you will need to obtain permission directly from the copyright holder. To view a copy of this license, visit http://creativecommons.org/ licenses/by/4.0/.

(C) The Author(s) 2017 